Hydrol. Earth Syst. Sci., 17, 2393-2413, 2013

www.hydrol-earth-syst-sci.net/17/2393/2013/

doi:10.5194/hess-17-2393-2013

(C) Author(s) 2013. CC Attribution 3.0 License.

\title{
A global water scarcity assessment under Shared Socio-economic Pathways - Part 2: Water availability and scarcity
}

\author{
N. Hanasaki ${ }^{1}$, S. Fujimori ${ }^{1}$, T. Yamamoto ${ }^{2}$, S. Yoshikawa ${ }^{3}$, Y. Masaki ${ }^{1}$, Y. Hijioka ${ }^{1}$, M. Kainuma ${ }^{1}$, Y. Kanamori ${ }^{1}$, \\ T. Masui ${ }^{1}$, K. Takahashi ${ }^{1}$, and S. Kanae ${ }^{3}$ \\ ${ }^{1}$ National Institute for Environmental Studies, Tsukuba, Japan \\ ${ }^{2}$ Nagaoka National College of Technology, Nagaoka, Japan \\ ${ }^{3}$ Tokyo Institute of Technology, Tokyo, Japan
}

Correspondence to: N. Hanasaki (hanasaki@nies.go.jp)

Received: 28 November 2012 - Published in Hydrol. Earth Syst. Sci. Discuss.: 18 December 2012 Revised: 8 May 2013 - Accepted: 9 May 2013 - Published: 1 July 2013

\begin{abstract}
A global water scarcity assessment for the $21 \mathrm{st}$ century was conducted under the latest socio-economic scenario for global change studies, namely Shared Socioeconomic Pathways (SSPs). SSPs depict five global situations with substantially different socio-economic conditions. In the accompanying paper, a water use scenario compatible with the SSPs was developed. This scenario considers not only quantitative socio-economic factors such as population and electricity production but also qualitative ones such as the degree of technological change and overall environmental consciousness. In this paper, water availability and water scarcity were assessed using a global hydrological model called H08. H08 simulates both the natural water cycle and major human activities such as water abstraction and reservoir operation. It simulates water availability and use at daily time intervals at a spatial resolution of $0.5^{\circ} \times 0.5^{\circ}$. A series of global hydrological simulations were conducted under the SSPs, taking into account different climate policy options and the results of climate models. Water scarcity was assessed using an index termed the $\mathrm{Cu}$ mulative Abstraction to Demand ratio, which is expressed as the accumulation of daily water abstraction from a river divided by the daily consumption-based potential water demand. This index can be used to express whether renewable water resources are available from rivers when required. The results suggested that by 2071-2100 the population living under severely water-stressed conditions for SSP1-5 will reach $2588-2793 \times 10^{6}$ (39-42\% of total population), 3966$4298 \times 10^{6}(46-50 \%), 5334-5643 \times 10^{6}(52-55 \%), 3427-$ $3786 \times 10^{6}(40-45 \%), 3164-3379 \times 10^{6}(46-49 \%)$ respec-
\end{abstract}

tively, if climate policies are not adopted. Even in SSP1 (the scenario with least change in water use and climate) global water scarcity increases considerably, as compared to the present-day. This is mainly due to the growth in population and economic activity in developing countries, and partly due to hydrological changes induced by global warming.

\section{Introduction}

Water resources are essential to all societal and economic activities. Total global water use is increasing, mainly due to economic and population growth in developing countries (Shiklomanov, 2000; Vörösmarty et al., 2000; Oki et al., 2003; Oki and Kanae, 2006; Alcamo et al., 2007). Moreover, as a consequence of climate change, water availability is projected to become restricted in many parts of the world from a hydrological perspective (Arnell, 1999, 2004; Kundzewitz et al., 2007; Döll, 2009).

We present a novel global water scarcity assessment, which identifies the regions and periods vulnerable to water scarcity following global climate change. The objectives of our research are threefold (see the accompanying paper for detail; Hanasaki et al., 2013). First, we conducted a global water resources assessment under the latest set of scenarios for global climate change studies (Moss et al., 2010). This consists of the socio-economic scenario of Shared Socioeconomic Pathways (SSPs; Kriegler et al., 2012), the radiative forcing (i.e. greenhouse gas (GHG) emission) scenario of the Representative Concentration Pathways (RCPs; van 
Vuuren et al., 2011), and the climate scenario of the Coupled Model Intercomparison Project Phase 5 (CMIP5; Taylor et al., 2012). Second, we developed a water use scenario that is compatible with both the qualitative and quantitative aspects of the SSPs. Third, we assessed whether renewable water resources are available when they are needed at daily intervals.

Our study is presented in a two-part paper. In the accompanying paper (Hanasaki et al., 2013), we developed a water use scenario compatible with the five global situations described in the SSPs. The scenario covers all of the 21 st century at five year intervals, with a spatial resolution of $0.5^{\circ} \times 0.5^{\circ}$. It includes five factors, namely, the irrigated area, crop intensity, irrigation efficiency, and withdrawalbased potential industrial and municipal water demands. In this paper we have conducted a series of numerical simulations using a global water resources model called H08 (Hanasaki et al., 2008a, b). The model is able to simulate both the natural water cycle and human water use together with their interaction. The impact of different socioeconomic conditions and climate change on water availability and use were analyzed for various combinations of scenarios.

The structure of this paper is as follows. In Sect. 2, the models, input data and simulation settings are presented. The simulation results are discussed in Sects. 3 and 4. In Sect. 3, we analyzed the impact of climate change excluding socioeconomic change. In Sect. 4 we analyzed the impact of both kinds of change. In Sect. 5, we summarize the key uncertainties in our study. In Sect. 6, we present our conclusions.

\section{Materials and methods}

\subsection{Global water resources model H08}

To estimate global water scarcity, we used the H08 global distributed hydrological model. A brief description of the H08 model is presented here, which is directly relevant to the results. A more detailed description is found in Hanasaki et al. (2006, 2008a, b).

H08 consists of six submodels, namely, land surface hydrology, river routing, crop growth, reservoir operation, water abstraction, and environmental flow requirement. The land surface hydrology submodel is a single soil layer model solving both the surface energy and water balance. The river submodel is a single reservoir model assuming constant flow velocity. The crop growth submodel is a process-based crop model based on the formulation of the SWIM (Soil and Water Integrated Model) model (Krysanova et al., 2000). This submodel is used to estimate the crop calendar (e.g. planting date, harvesting date and cropping period), which is essential to estimate the daily irrigation water requirement. Consumption-based potential irrigation water demand is defined as the irrigation water required to maintain soil moisture in the top $1 \mathrm{~m}$ of irrigated cropland at $75 \%$ (100\% for rice) during the cropping period. The reservoir operation submodel determines the storage and release of 507 reservoirs worldwide with a storage capacity larger than $1.0 \times 10^{9} \mathrm{~m}^{3}$ (Hanasaki et al., 2006). Each reservoir is individually located on the river map of H08. For reservoirs for which the primary purpose is irrigation water supply, the release is controlled to match the seasonal variation of consumption-based potential irrigation water demand in the lower reach. For reservoirs with other purposes, release and storage is controlled to minimize seasonal and inter-annual variations in river flows, taking into account the ratio of the storage capacity of reservoirs and mean annual inflow. The environmental flow requirement submodel is a simple empirical model that estimates the amount of river discharge that should be kept in the channel to maintain the aquatic ecosystem. The model is based on case studies of regional practices, while the river discharge should ideally be unchanged for the preservation of the natural environment.

The water abstraction submodel abstracts water from rivers to meet the consumption-based potential water demand. Note that only consumptive water use is included and not return flow and delivery loss. Because the river submodel is relatively simple (see Oki et al., 1999 in detail), the flow velocity is not affected by water abstraction or environmental flows. When large reservoirs are located in the upper stream, the river is affected by reservoir operation. H08 prioritizes the simulation of municipal water abstraction, followed by industrial and irrigation water abstraction. Note that although Hanasaki et al. (2010) incorporated some additional subcomponents into $\mathrm{H} 08$, such as medium-sized reservoirs (reservoirs with storage capacity less than $1.0 \times 10^{9} \mathrm{~m}^{3}$ capacity) and non-local and non-renewable blue water (hypothetical water sources to close the balance of local water supply and demand) they were excluded in this study because these terms include considerable uncertainties both in modeling and developing future scenarios. However, we did include the 507 largest reservoirs, because they considerably affect the river discharge of the largest rivers in the world (Hanasaki et al., 2006; Haddeland et al., 2006). A schematic diagram of water abstraction is shown in Fig. 1.

The performance of $\mathrm{H} 08$ has been assessed in earlier publications. Hanasaki et al. (2008a, b) applied H08 globally at a $1^{\circ} \times 1^{\circ}$ spatial resolution and at daily time intervals for the period 1986-1995. They used data from the second Global Soil Wetness Project (GSWP2) circa 1990 and found that H08 reproduced monthly river discharge at the continental scale and for major river basins (Hanasaki et al., 2008a), as well as nation-wide mean annual irrigation water withdrawal (Hanasaki et al., 2008b). Haddeland et al. (2011) conducted an inter-comparison of global hydrological models. They ran 13 models under a common simulation protocol, and compared hydrological variables such as river discharge, evaporation, and snowmelt. The results showed that $\mathrm{H} 08$ is within the plausible range of modern macro-scale hydrological models for most basins. 


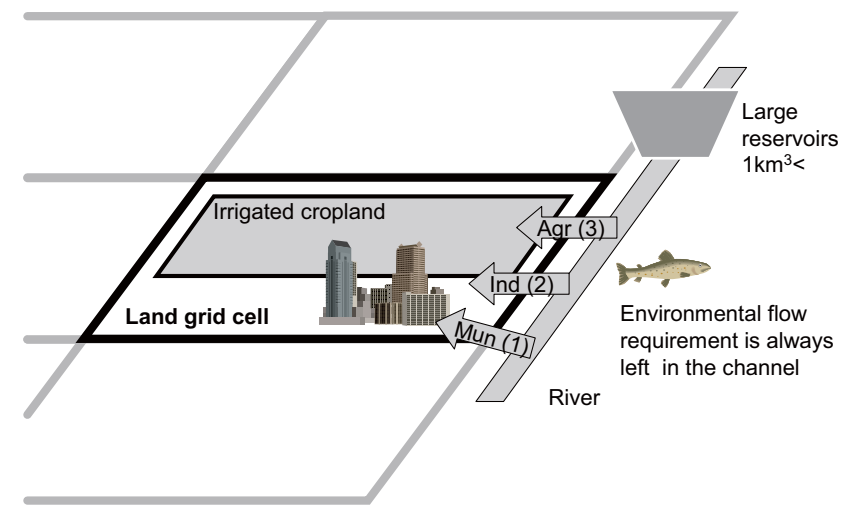

Fig. 1. Schematic diagram of water abstraction in H08. Water is only abstracted from rivers. A river is considered to be regulated if there are large reservoirs with a storage capacity of greater than $1.0 \times 10^{9} \mathrm{~m}^{3}$. Water is abstracted to fulfill potential municipal, industrial, and irrigation water demands on a daily basis. The environmental flow requirement (between $0-40 \%$ of mean monthly river discharge) is always left in the river channel.

\subsection{Meteorological data and scenarios}

H08 requires the input of the eight meteorological variables listed in Table 1. For historical simulations, WATCH (Water and Global Change project) forcing data (Weedon et al., 2011; hereafter WFD) was used. WFD covers the whole globe at a $0.5 \times 0.5^{\circ}$ spatial resolution. It covers the time period 1958-2001 at six-hourly intervals. We converted WFD into daily intervals, and used 1971-2000 as the base period.

For future simulations, the climate scenario of the CMIP5 was used. CMIP5 coordinates climate projections using global climate models (Taylor et al., 2012). As of October 2012, the results of more than 40 global climate models (GCMs) have been available via the internet. Although it is recommended to utilize all available GCMs to account for model uncertainty (Knutti et al., 2010), for practical reasons, we needed to restrict the number of GCMs used. We subjectively selected three GCMs, namely MIROC-ESMCHEM (MIROC), HadGEM2-ES (HadGEM2), and GFDLESM2M (GFDL) (Table 2). There is an open discussion regarding the selection of models (Knutti et al., 2010), but the models selected in this study are used in the Inter Sectoral Impact Model Intercomparison Project (ISI-MIP; http://www.isi-mip.org/), which enabled cross-checking with their results.

It is widely known that the output of GCMs contain systematic biases. In this study, we corrected for the biases of air temperature, precipitation, and longwave downward radiation. Most of the earlier studies corrected only for air temperature and precipitation. We included longwave downward radiation, because this term shows an apparent increasing trend in all GCM projections. Moreover, this term is important in solving the surface energy balance. To remove bias, a shifting and scaling methodology was used (e.g. Alcamo et al., 2007; Lehner et al., 2006).

$$
\begin{aligned}
& T_{\mathrm{y}, \mathrm{m}, \mathrm{d}}^{\mathrm{cor}}=T_{\mathrm{y}, \mathrm{m}, \mathrm{d}}^{\mathrm{obs}}+\left(\bar{T}_{\text {future, } \mathrm{m}}^{\mathrm{org}}-\bar{T}_{\text {baseline, } \mathrm{m}}^{\mathrm{org}}\right) \\
& P_{\mathrm{y}, \mathrm{m}, \mathrm{d}}^{\mathrm{cor}}=P_{\mathrm{y}, \mathrm{m}, \mathrm{d}}^{\mathrm{obs}} \times\left(\bar{P}_{\text {future } \mathrm{m}}^{\mathrm{org}} \div \bar{P}_{\mathrm{baseline}, \mathrm{m}}^{\mathrm{org}}\right) \\
& L_{\mathrm{y}, \mathrm{m}, \mathrm{d}}^{\mathrm{cor}}=L_{\mathrm{y}, \mathrm{m}, \mathrm{d}}^{\mathrm{obs}} \times\left(\bar{L}_{\text {future } \mathrm{m}}^{\mathrm{org}}-\bar{L}_{\mathrm{baseline}, \mathrm{m}}^{\mathrm{org}}\right),
\end{aligned}
$$

where $T, P$, and $L$ denote air temperature, precipitation, and longwave radiation, respectively. The superscripts cor, obs, and org denote bias-corrected, observation and original GCM values, respectively. The subscripts future, baseline $\mathrm{y}, \mathrm{m}, \mathrm{d}$ indicate future period, retrospective period, year, month, and day, respectively. The upper bar indicates that the mean of thirty years' records has been taken. After correcting for temperature and precipitation, rainfall-snowfall separation was conducted following the method of Kondo (1994), which uses not only air temperature but also relative humidity.

\subsection{Non-meteorological data and scenarios}

H08 requires the input of the non-meteorological variables listed in Table 3. For the other parameters of H08, we used the default values, as shown in Hanasaki et al. (2008a, b, 2010). For historical simulations, we used published datasets, which represent the period circa 2000. For future simulations, we used scenarios developed in the accompanying paper (Hanasaki et al., 2013) for the irrigated area, crop intensity, irrigation efficiency, and withdrawal-based potential industrial and domestic water demand. Due to a lack of available information, the other variables were kept at present levels.

Crop type was set by using the crop type data of Monfreda et al. (2008). They provided the areal fraction of 175 crop types, but we used only 19 that are commonly cultivated worldwide. $\mathrm{H} 08$ is able to simulate up to two crops per year (multiple-cropping is common in the tropics), but needs to select only one crop type per grid cell during a cropping period (from planting to harvesting date). Here we assumed that the crop type of the largest fraction is planted in the first crop, and that of the second largest is in the second. We fixed the crop type throughout the 21 st century, because of a lack of available data. This might be unrealistic because farmers would change the crop type to adapt to a changing climate and the demands of the crop. Because it is beyond the scope of this study to discuss future agricultural practices and food production, we left the crop type scenario until such time as the integrated assessment community can provide relevant scenarios and guidelines (see also the discussion in Sects. 3 and 6 of Hanasaki et al., 2013).

Potential water demand for industrial and municipal use is provided as the withdrawal base. To convert this into a consumption base, which is used to calculate the Cumulative Abstraction to Demand index explained below, we used 
Table 1. Meteorological variables.

\begin{tabular}{lll}
\hline Item & Baseline (1971-2000) & Future \\
\hline Rainfall $\left[\mathrm{kg} \mathrm{m}^{-2} \mathrm{~s}^{-1}\right]$ & Weedon et al. (2011) & Scaling \& separation (see text) \\
Snowfall $\left[\mathrm{kg} \mathrm{m}^{-2} \mathrm{~s}^{-1}\right]$ & & Scaling \& separation (see text) \\
Air temperature $[\mathrm{K}]$ & Shifting (see text) \\
Longwave downward radiation $\left[\mathrm{W} \mathrm{m}^{-2}\right]$ & Shifting (see text) \\
Shortwave downward radiation $\left[\mathrm{W} \mathrm{m}^{-2}\right]$ & Fixed at present \\
Relative humidity [\%] & Fixed at present \\
Wind speed $\left[\mathrm{m} \mathrm{s}^{-1}\right]$ & Fixed at present \\
Air pressure $[\mathrm{Pa}]$ & Fixed at present \\
\hline
\end{tabular}

Table 2. Global climate models used in this study.

\begin{tabular}{ll}
\hline Modeling center & Model name \\
\hline Japan Agency for Marine-Earth Science and Technology, Atmosphere and Ocean Research & MIROC-ESM-CHEM \\
Institute (University of Tokyo), and National Institute for Environmental Studies & \\
Met Office Hadley Centre & HadGEM2-ES \\
NOAA Geophysical Fluid Dynamics Laboratory & GFDL-ESM2M \\
\hline
\end{tabular}

the factors 0.10 and 0.15 respectively, from the work of Shiklomanov (2000). These values should be varied by country, time, and technological development. Because of a lack of information, we fixed these values throughout all countries, simulation periods, and scenarios. The values used could be too optimistic for developing countries with limited water recycling technology. Potential water demand for irrigation use is simulated by $\mathrm{H} 08$ as the consumption base. To convert this into the withdrawal base, which is used to calculate the Withdrawal to Water Resources index explained below, we used the irrigation efficiency scenario developed in the accompanying paper (Hanasaki et al., 2013).

\subsection{Simulation settings}

We configured models and set up a simulation protocol as shown in Tables 4 and 5. We configured H08 in two forms, first for naturalized simulation (NAT), using only land surface and river submodels, and second for human simulation (HUM), using all six submodels. The NAT was used to assess a situation that assumed there was no human activity at all during the simulation periods, in order to evaluate the impact of climate change on the hydrological cycle. The HUM was used to assess water scarcity.

For the baseline period (1971-2000), two simulations were conducted with a naturalized configuration (NATBaseline) and human configuration (HUM-Baseline).

For the future periods, we conducted four simulations: naturalized configuration (NAT-Future), human configuration fixing non-meteorological variables at circa 2000 (HUMFix), using the SSPs without a climate policy (business as usual; HUM-BAU), and using the SSPs with a climate pol- icy (HUM-Policy). Three simulation periods were set, 20112040, 2041-2070 and 2071-2100.

The NAT-Future simulation was conducted to analyze the hydrological response to climate change. H08 was set to a naturalized configuration, and future meteorological data (Eqs. 1-3) were prepared for three RCPs (RCP2.6, 4.5, 8.5) and three GCMs (MIROC, HadGEM2, GFDL).

The HUM-Fix simulation was conducted to analyze the magnitude of change in water availability and use due to climate change, excluding the effect of socio-economic changes. Three RCPs were used for three GCMs, but nonmeteorological variables were fixed at the baseline period.

The HUM-BAU simulation was conducted to analyze water availability and scarcity under a business-as-usual situation, with no climate policy. All five of the SSP scenarios were used. For each scenario, a RCP was selected that was compatible with the emission path as described in the accompanying paper (Table 5, see also Fig. 3 of Hanasaki et al., 2013). Note that because the RCPs and SSPs have been developed independently, consistency between them is not strictly assured.

The HUM-Policy simulation was conducted to evaluate how climate policies alleviate water scarcity for each SSP. All five of the SSP scenarios were used. In this study, climate policy switches RCPs into lower levels (Table 5, see also Fig. 3 of Hanasaki et al., 2013). Again note that the consistency of RCPs, SSPs, and the policy scenarios are not fully assured. Climate policy simulations in this study were conducted primarily to determine the response to a lower level of climate change. Although not available as of October 2012, a climate policy scenario called Shared Policy Assumptions (SPA) is under discussion (Kriegler et al., 2012). 
Table 3. Non-meteorological variables.

\begin{tabular}{lll}
\hline Item & Baseline (circa 2000) & $\begin{array}{l}\text { Future (2005-2100, } \\
\text { for each SSP1/2/3/4/5) }\end{array}$ \\
\hline $\begin{array}{l}\text { Irrigated area } \\
\text { Crop intensity }\end{array}$ & $\begin{array}{l}\text { Siebert et al. (2005) } \\
\text { Döll and Siebert (2002) }\end{array}$ & $\begin{array}{l}\text { See Table 5 } \\
\text { See Table 5 }\end{array}$ \\
Irrigation efficiency & $\begin{array}{l}\text { Döll and Siebert (2002) } \\
\text { Areal fraction of non-cropland }\end{array}$ & See Table 5 \\
Crop type & Ramankutty et al. (2008) & Fixed at circa 2000 \\
Withdrawal-based potential industrial water demand & Monfreda et al. (2008) & Fixed at circa 2000 \\
Withdrawal-based potential municipal water demand & FAO (2011) & See Table 5 \\
Crop planting date & FAO (2011) & See Table 5 \\
Environmental flow requirement & Simulated & Fixed at circa 2000 \\
Large size reservoir & Simulated & Fixed at circa 2000 \\
& ICOLD (1998); & Fixed at circa 2000 \\
\hline
\end{tabular}

Table 4. Simulation settings.

\begin{tabular}{llllcc}
\hline & $\begin{array}{l}\text { Non-meteorological } \\
\text { variables }\end{array}$ & $\begin{array}{l}\text { Emission } \\
\text { scenarios }\end{array}$ & Period & $\begin{array}{c}\text { Land and river } \\
\text { sub-models }\end{array}$ & $\begin{array}{c}\text { Other } \\
\text { sub-models }\end{array}$ \\
\hline $\begin{array}{l}\text { NAT-Baseline } \\
\text { HUM-Baseline }\end{array}$ & See Baseline of Table 3 & & $1971-2000$ & $\mathrm{X}$ & \\
NAT-Future & & $1971-2000$ & $\mathrm{X}$ & $\mathrm{X}$ \\
HUM-Fix & See Baseline of Table 3 & RCP2.6/4.5/8.5 & $2011-2040,2041-2070,2071-2100$ & $\mathrm{X}$ & $\mathrm{X}$ \\
HUM-BAU & See Future of Table 3 & See Table 5 & $2041-2070,2071-2100$ & $\mathrm{X}$ \\
HUM-Policy & See Future of Table 3 & See Table 5 & $2041-2070,2071-2100$ & $\mathrm{X}$ & $\mathrm{X}$ \\
\hline
\end{tabular}

\subsection{Water scarcity index}

Many earlier studies assessed water scarcity using an index called the Withdrawal to Water Resources (WWR) ratio, which was devised by Raskin et al. (1997). The index expresses annual water withdrawal as a function of annual renewable water resources.

$\mathrm{WWR}=W / Q$,

where $Q$ is the annual renewable water resource, typically substituted with mean annual river discharge $\left[\mathrm{m}^{3} \mathrm{~s}^{-1}\right]$ and $W$ is the annual total water withdrawal $\left[\mathrm{m}^{3} \mathrm{~s}^{-1}\right]$. If water withdrawal exceeds $40 \%$ of the water resources in a region, a chronic water shortage is indicated. This index is widely used, probably because it is intuitive and requires only two factors ( $W$ and $Q$ ) that are relatively easily available. However, there are some well-known problems with the use of the WWR that are particularly important when it is applied to the assessment of climate change impacts. Climate change is projected to increase mean annual river discharges in many parts of the world, with an accompanying increase in the frequency and magnitude of the risk of floods and droughts (Kundzewitz et al., 2007). Because all of these variations are smoothed when the mean annual river discharge (i.e. the denominator of Eq. 4) is calculated, the WWR unintentionally underestimates these risks. A few studies have reported countermeasures. Wada et al. (2011) and Hoekstra et al. (2012) computed the WWR on a monthly basis. Alcamo et al. (2007) proposed the consumption-to-Q90 ratio. Here"consumption" is the average monthly volume of water that is evaporated and "Q90" is a measure of the monthly river discharge that occurs under dry conditions (monthly discharge exceeds the Q90 value for $90 \%$ of the time). These approaches successfully identify the water scarcity in the most stressed month of the year, but do not easily determine water scarcity throughout the year as a whole. Hanasaki et al. (2008b) devised an index called the Cumulative Abstraction to Demand (CAD) ratio. The index was designed for modern global hydrological models, which can explicitly simulate the daily river discharge and water abstraction. This index is expressed as

$\mathrm{CAD}=\sum_{\mathrm{DOY}=1}^{365} a_{\mathrm{DOY}} / \sum_{\mathrm{DOY}=1}^{365} d_{\mathrm{DOY}}$,

where $a_{\text {DOY }}$ and $d_{\text {DOY }}$ denote the simulated daily water abstraction from a river and the daily consumption-based potential water demand for a day of the year (DOY), respectively. If the accumulated water abstraction from the river (numerator) falls below the accumulated consumption-based potential water demand (denominator), water scarcity is indicated. $a_{\mathrm{DOY}} \leq d_{\mathrm{DOY}}$ can occur when a water source (i.e. a river) is depleted. In this way, the index directly indicates whether the water is available when it is needed. 
Table 5. Combination of SSPs and RCPs. See Table 5 of Hanasaki et al. (2013) for the scenario of irrigated area and crop intensity growth. See Tables 6, 7, 8 of Hanasaki et al. (2013) for the improvement in efficiency of irrigation, industrial, and domestic water use, respectively.

\begin{tabular}{|c|c|c|c|c|c|c|c|}
\hline & & \multirow[t]{2}{*}{ Irrigated area } & \multirow[t]{2}{*}{ Crop intensity } & \multicolumn{3}{|c|}{ Efficiency improvement } & \multirow{2}{*}{$\begin{array}{l}\text { Emission } \\
\text { Scenario }\end{array}$} \\
\hline & & & & Irrigation water use & Industrial water use & Domestic water use & \\
\hline SSP1 & $\begin{array}{l}\text { BAU } \\
\text { Policy }\end{array}$ & Low Growth & Low Growth & High Efficiency & High Efficiency & High Efficiency & $\begin{array}{l}\text { RCP6.0 } \\
\text { RCP2.6 }\end{array}$ \\
\hline SSP2 & $\begin{array}{l}\text { BAU } \\
\text { Policy }\end{array}$ & Medium Growth & Medium Growth & Medium Efficiency & Medium Efficiency & Medium Efficiency & $\begin{array}{l}\text { RCP8.5 } \\
\text { RCP4.5 }\end{array}$ \\
\hline SSP3 & $\begin{array}{l}\text { BAU } \\
\text { Policy }\end{array}$ & High Growth & High Growth & Low Efficiency & Low Efficiency & Low Efficiency & $\begin{array}{l}\text { RCP8.5 } \\
\text { RCP6.0 }\end{array}$ \\
\hline SSP4 & $\begin{array}{l}\text { BAU } \\
\text { Policy }\end{array}$ & Low Growth & Low Growth & Mixture of Efficiency & Mixture of Efficiency & Mixture of Efficiency & $\begin{array}{l}\text { RCP6.0 } \\
\text { RCP2.6 }\end{array}$ \\
\hline SSP5 & $\begin{array}{l}\text { BAU } \\
\text { Policy }\end{array}$ & High Growth & High Growth & High Efficiency & High Efficiency & High Efficiency & $\begin{array}{l}\text { RCP8.5 } \\
\text { RCP6.0 }\end{array}$ \\
\hline
\end{tabular}

This index is conceptual and for simulation only. In reality, not only river water but also groundwater, water stored in reservoirs and water diverted from different river basins are sources of water. In numerical simulations, all of these factors can be disabled, allowing the relationship between the natural hydrological cycle and human-water demand to be analyzed. When the CAD falls below unity, it does not necessarily indicate that a region is experiencing a water shortage, but it does indicate the need for an alternative source of water other than natural river flow.

Hanasaki et al. (2008b) estimated the CAD globally using the H08 water resources model. They identified regions that experience a gap in their subannual distribution of water availability and water use, including the Sahel, the Asian monsoon region, and southern Africa. Due to the large contrast between wet and dry seasons, these regions frequently suffer from seasonal water shortages in dry periods. They retrospectively assessed the period of 1986-1995, but not under climate change conditions. Thus, the CAD is used for a global change impact assessment on water scarcity for the first time in this study.

\section{Results and discussion Part 1: impact of climate change}

This section provides basic information regarding the response of hydrology and the water scarcity index to climate change. Socio-economic change is excluded on purpose. Both climate and socio-economic change are considered in the next section.

In this section, we analyze the results of the NAT-Future and HUM-Fix simulations and compare them with the NATBaseline and HUM-Baseline simulations, respectively. The results of the HUM-Baseline simulation are shown in Fig. 2. As can be seen from Table 4, non-meteorological data, such as population and land use, was not used or fixed at the baseline period in these settings.

\subsection{Climate change}

First, we focus on the change in air temperature, which indicates the magnitude of climate change. We then consider the change in precipitation, which directly impacts water resources and consumption-based potential irrigation water demand.

Tables 6 and 7 show the changes in mean global terrestrial (i.e. land only excluding the Antarctica) temperature and precipitation, respectively. The projected rise of global terrestrial mean temperature in 2071-2100, compared to the baseline period (1971-2000), was 1.2-2.4 K (RCP 2.6), 2.0-3.9 K (RCP 4.5), and 3.8-6.4 K (RCP 8.5). Global mean precipitation increased by $0.8-4.5,1.9-5.9$, and $3.6-9.5 \%$, respectively. The MIROC projection produced the largest increases among the three models. HadGEM2 projected a similar temperature rise to MIROC, but the change in precipitation was slightly smaller. GFDL projected the least change in both temperature and precipitation among the three models, being less than half of MIROC and HadGEM2.

Figures 3 and 4 show the geographical patterns of global temperature rise and precipitation changes projected by MIROC. Only the results of MIROC are used for discussion of geographical patterns hereafter, because the model shows the largest change among the three used. The results of HadGEM and GFDL are available in the Supplement. From Figs. 3 and 4, it can be clearly seen that the spatial pattern of change is similar among periods and RCPs, and only the magnitude of change increases as time and radiative forcing increases from a macroscopic perspective. Although the other two models produced different spatial patterns and magnitudes, a generally consistent pattern was identified, where temperature in the northern high latitudes 
(a)Temperature

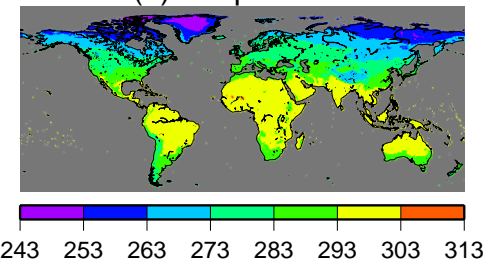

(d)Pot_Agri_Water_Demand

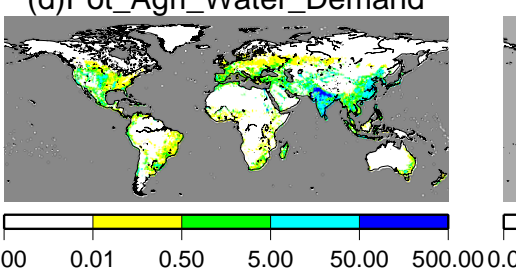

(b)Precipitation

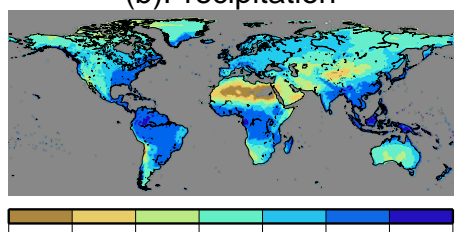

(e)WWR

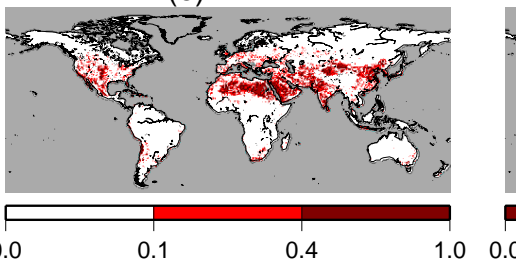

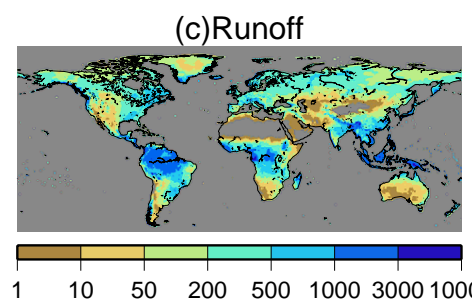

(f)CWD

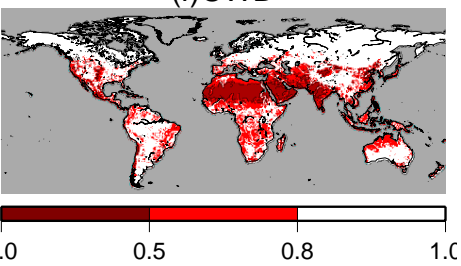

Fig. 2. Input and output of the HUM-Baseline simulation. (a) Air temperature [K], (b) precipitation [mm $\left.\mathrm{yr}^{-1}\right]$, (c) total runoff [mm $\left.\mathrm{yr}^{-1}\right]$, (d) withdrawal-based potential irrigation water demand $\left[\mathrm{m}^{3} \mathrm{~s}^{-1}\right]$, (e) withdrawal to water resources ratio (WWR) [-], and (f) cumulative abstraction to demand ratio (CAD) [-]. Gray indicates missing values.
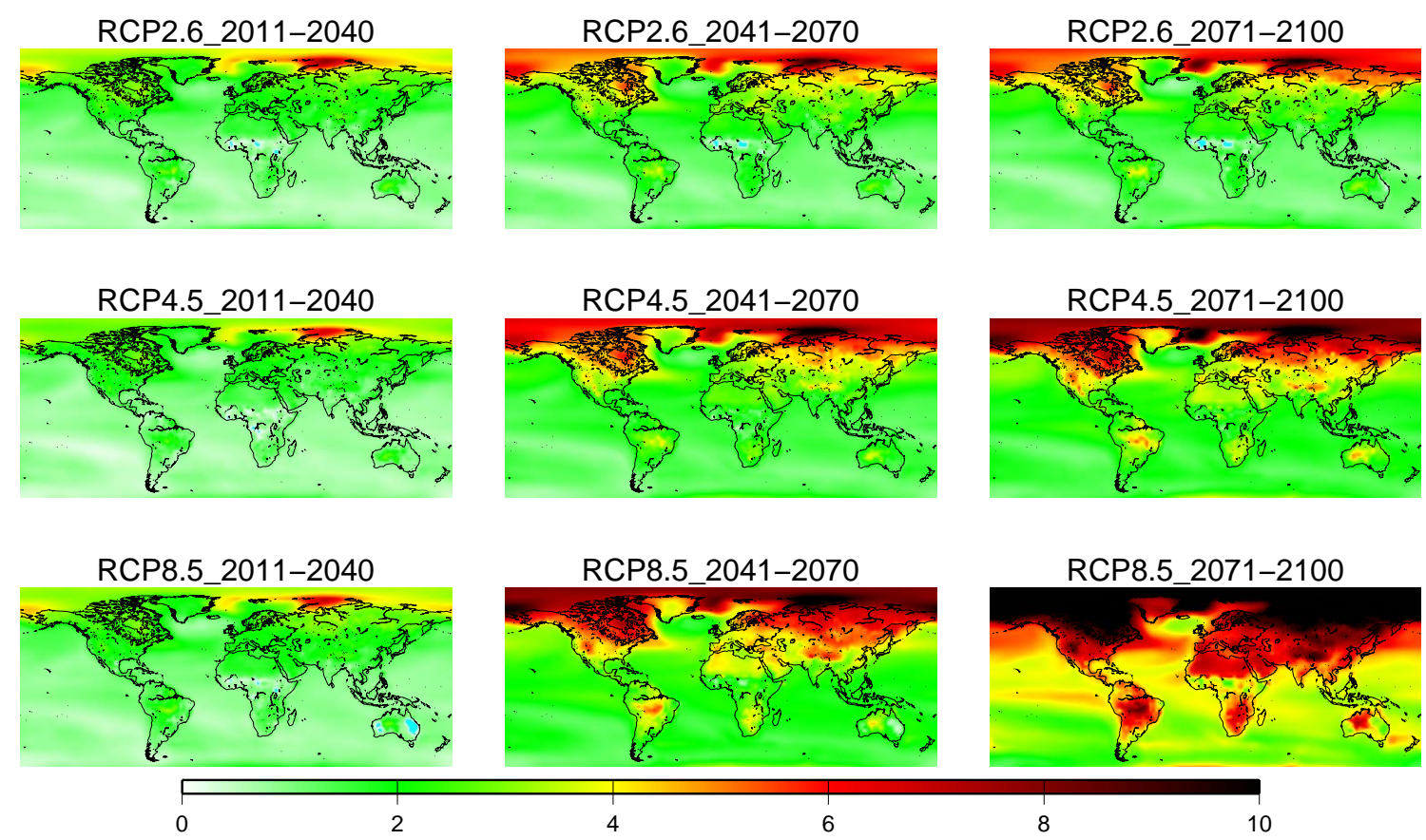

Fig. 3. Global pattern of change (difference) in mean annual temperature from the baseline period [K].

increased rapidly, as compared to the low latitudes. Precipitation decreased in semi-arid areas such as near the Mediterranean Sea, central to western mid-latitude North America, southern Africa and southeastern South America. One important finding, as shown by Tables $6-7$ and Figs. 3-4 is that there is no clear difference when using RCP2.6, RCP4.5, and RCP8.5 in 2011-2040. There are distinct differences after 2041-2070 in terms of both the mean global changes and geographical patterns.

\subsection{Hydrological change}

Next, the change in mean estimated annual runoff is discussed. Mean annual runoff is a key variable in the assessment of water resources, because it corresponds to regional renewable water resources. We focused on the results of the NAT-Future simulation, which displayed a hydrological response to climate change.

Table 8 shows the estimated change in runoff for each scenario and period. The increase in runoff matched the change in global mean precipitation (Table 7). For example, MIROC 

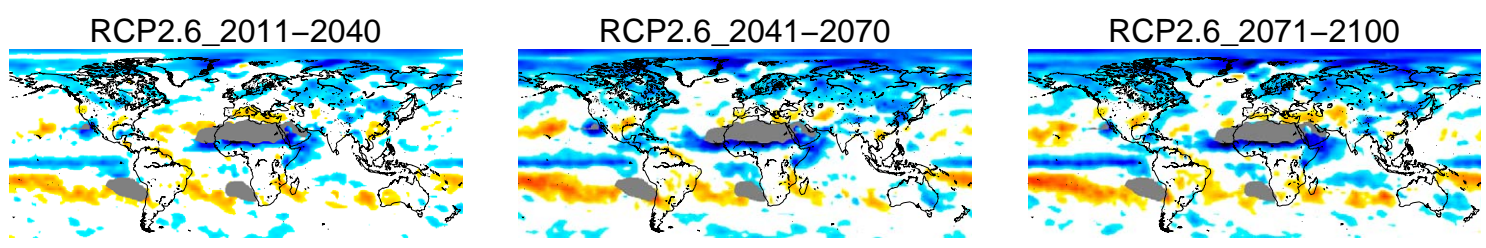

RCP4.5 2011-2040

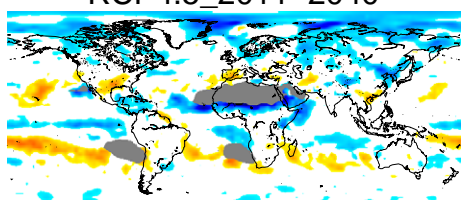

RCP8.5_2011-2040

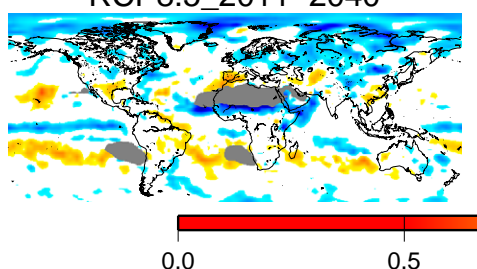

RCP4.5 2041-2070

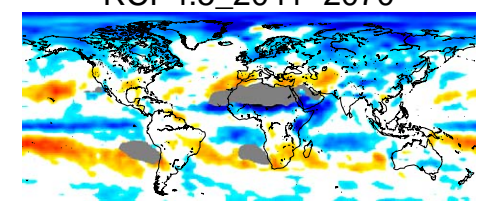

RCP8.5_2041-2070

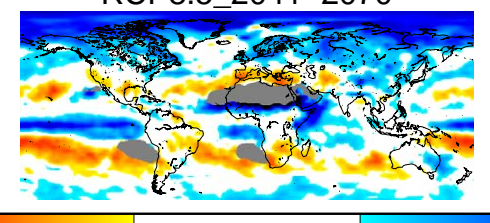

RCP4.5 2071-2100

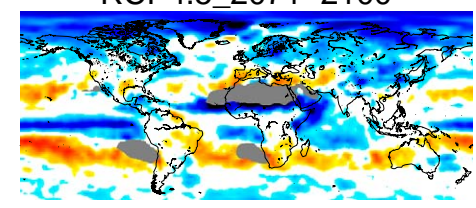

RCP8.5_2071-2100

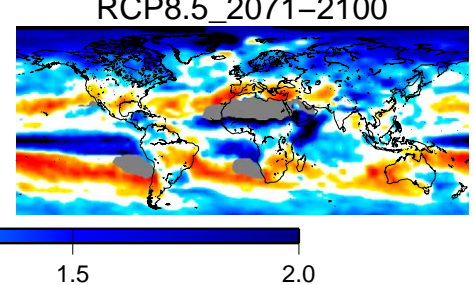

Fig. 4. Global patterns of change (ratio) in the mean annual precipitation from the baseline period [-]. Regions shown in gray indicate that the precipitation was less than $10 \mathrm{~mm}$ per month equivalent, and for this condition a precipitation bias correction was not applied (see text).

Table 6. Global terrestrial mean temperature change projected by the three GCMs. Baseline period (1971-2000) is 286.2 K.

\begin{tabular}{|c|c|c|c|c|c|c|c|c|c|}
\hline & \multicolumn{3}{|c|}{ RCP2.6 } & \multicolumn{3}{|c|}{$\mathrm{RCP} 4.5$} & \multicolumn{3}{|c|}{ RCP8.5 } \\
\hline & 2011-2040 & 2041-2070 & $2071-2100$ & 2011-2040 & 2041-2070 & $2071-2100$ & 2011-2040 & 2041-2070 & $2071-2100$ \\
\hline MIROC & $1.7 \mathrm{~K}$ & $2.4 \mathrm{~K}$ & $2.4 \mathrm{~K}$ & $1.5 \mathrm{~K}$ & $2.9 \mathrm{~K}$ & $3.6 \mathrm{~K}$ & $1.7 \mathrm{~K}$ & $3.8 \mathrm{~K}$ & $6.3 \mathrm{~K}$ \\
\hline HadGEM & $1.8 \mathrm{~K}$ & $2.4 \mathrm{~K}$ & $2.3 \mathrm{~K}$ & $1.7 \mathrm{~K}$ & $3.1 \mathrm{~K}$ & $3.9 \mathrm{~K}$ & $1.9 \mathrm{~K}$ & $4.0 \mathrm{~K}$ & $6.4 \mathrm{~K}$ \\
\hline GFDL & $1.1 \mathrm{~K}$ & $1.3 \mathrm{~K}$ & $1.2 \mathrm{~K}$ & $1.2 \mathrm{~K}$ & $1.8 \mathrm{~K}$ & $2.0 \mathrm{~K}$ & $1.2 \mathrm{~K}$ & $2.4 \mathrm{~K}$ & $3.8 \mathrm{~K}$ \\
\hline
\end{tabular}

projected the largest increase in runoff among the three models, which is consistent with the change in precipitation.

Figure 5 shows the geographical pattern of the change in runoff. Although the pattern of runoff changes (i.e. redblue distribution) was similar to that of precipitation changes (Fig. 4), there was a much stronger contrast with the regional pattern (the color schemes are identical for Figs. 4 and 5). Generally, runoff increased in the northern high latitudes and decreased in the mid-latitudes. The figure indicates that, for MIROC under the RCP8.5 scenario, the mean annual runoff in 2071-2100 was altered by more than $10 \%$ from the baseline period, in almost all regions of the world.

\subsection{Withdrawal-based potential irrigation water demand}

Next, the simulated withdrawal-based potential irrigation water demand is discussed using the results of HUM-Fix simulations. Table 9 shows the projected change in global total withdrawal-based potential irrigation water demand. The projected ranges for RCP2.6, RCP4.5, and RCP8.5 were
$-0.2-1.6,1.9-2.8$, and $6.7-10.0 \%$, respectively, in $2071-$ 2100. This indicates that the total global withdrawal-based potential irrigation water demand increases in almost all scenarios. This is consistent with the findings of Döll (2002) who reported the results of similar numerical experiments. The difference among models and scenarios was small in 2011-2040, but became more distinct after 2041-2070.

Figure 6 shows the change in the mean annual withdrawalbased potential irrigation water demand projected by the MIROC. In 2011-2040, the change was no more than $\pm 10 \%$ in most of the world. In 2041-2070, the change exceeded $\pm 10 \%$ in many regions except for the Asian monsoon regions and Australia. In 2071-2100 and particularly for the results using RCP8.5, many regions displayed an increase or decrease larger than $\pm 10 \%$. This pattern is primarily explained by the increase in potential irrigation water demand in regions receiving less precipitation, and vice versa. In addition to precipitation, higher temperatures and downward longwave radiation also contribute to an increase in 


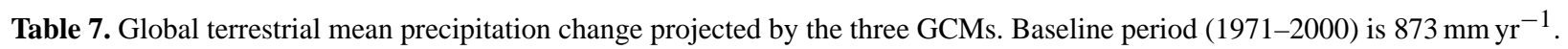

\begin{tabular}{|c|c|c|c|c|c|c|c|c|c|}
\hline & \multicolumn{3}{|c|}{ RCP2.6 } & \multicolumn{3}{|c|}{ RCP4.5 } & \multicolumn{3}{|c|}{ RCP8.5 } \\
\hline & 2011-2040 & $2041-2070$ & $2071-2100$ & $2011-2040$ & $2041-2070$ & $2071-2100$ & $2011-2040$ & $2041-2070$ & $2071-2100$ \\
\hline MIROC & $2.3 \%$ & $4.8 \%$ & $4.5 \%$ & $2.4 \%$ & $4.8 \%$ & $5.9 \%$ & $2.5 \%$ & $6.0 \%$ & $9.5 \%$ \\
\hline HadGEM & $2.1 \%$ & $2.9 \%$ & $3.4 \%$ & $2.4 \%$ & $3.8 \%$ & $5.2 \%$ & $2.5 \%$ & $4.1 \%$ & $4.3 \%$ \\
\hline GFDL & $0.5 \%$ & $0.9 \%$ & $0.8 \%$ & $0.4 \%$ & $1.8 \%$ & $1.9 \%$ & $1.0 \%$ & $1.7 \%$ & $3.6 \%$ \\
\hline
\end{tabular}

Table 8. Global mean runoff change projected by the three GCMs. Baseline period (1971-2000) is $407.6 \mathrm{~mm} \mathrm{yr}^{-1}$.

\begin{tabular}{|c|c|c|c|c|c|c|c|c|c|}
\hline & \multicolumn{3}{|c|}{ RCP2.6 } & \multicolumn{3}{|c|}{$\mathrm{RCP} 4.5$} & \multicolumn{3}{|c|}{ RCP8.5 } \\
\hline & $2011-2040$ & $2041-2070$ & $2071-2100$ & $2011-2040$ & $2041-2070$ & $2071-2100$ & $2011-2040$ & $2041-2070$ & $2071-2100$ \\
\hline MIROC & $1.7 \%$ & $5.1 \%$ & $4.7 \%$ & $2.5 \%$ & $4.5 \%$ & $6.2 \%$ & $2.3 \%$ & $5.6 \%$ & $9.6 \%$ \\
\hline HadGEM & $5.5 \%$ & $6.5 \%$ & $6.9 \%$ & $5.1 \%$ & $5.4 \%$ & $7.6 \%$ & $5.1 \%$ & $6.9 \%$ & $5.6 \%$ \\
\hline GFDL & $0.9 \%$ & $0.3 \%$ & $1.1 \%$ & $-0.4 \%$ & $2.8 \%$ & $3.1 \%$ & $1.5 \%$ & $2.3 \%$ & $4.3 \%$ \\
\hline
\end{tabular}

the potential evapotranspiration, which eventually leads to a higher water requirement.

\subsection{Withdrawal to water resources ratio}

Water scarcity was assessed using the WWR. We focused on both the index itself $(W / Q)$ and the so-called water-stressed population, which is defined here as the total population living in grid cells where the index exceeds 0.4 .

Table 10 shows the total global water-stressed population and highlights two interesting findings. First, the estimated water-stressed population varied only marginally across all scenarios. Second, there was no clear relationship between the water-stressed population and either time or GHG emissions (i.e. RCPs). In some simulations, water stress decreased as time progressed (e.g. when using RCP2.6 in MIROC the water-stressed population in 2041-2070 was smaller than in 2011-2040) or as GHG emissions increased (e.g. in 20712100 of MIROC, the water-stressed population using RCP4.5 was smaller than when using RCP2.6).

The minor changes in the water-stressed population can be primarily explained by the robustness of the index. In the HUM-Fix simulation, we fixed $W$ (the numerator of Eq. 4). Irrigation water withdrawal was also affected by climate change but the change was small. Therefore, $Q$ (the denominator) had the primary role in this assessment. Although climate change affected the hydrological cycle globally, it did not alter the spatial pattern of world climatic zones (i.e. fundamentally, the dry regions remained dry, and the wet regions remained wet). This prevented substantial change in the index. Consequently, densely populated grid cells where the index far exceeded 0.4 generated water-stressed population in all scenarios. The estimation of the total global waterstressed population was considered to be robust due to these factors.

To analyze the change in the water-stressed population, we focused on the change in WWR. Figure 7 shows the geo- graphical pattern of changes in the WWR. We defined the change as the ratio of WWR of the future period to the baseline, because WWR takes a wide range (almost zero in wet unpopulated regions to thousands in dry populated regions). The positive and negative signs basically correspond to the runoff scenario from Fig. 5. WWR increased where runoff decreased and vice versa. Note that the change was shifted toward the negative (i.e. water scarcity) direction, because global irrigation water withdrawal increased slightly (Fig. 6).

Table 10 shows the population living in the grid cells where water stress conditions improved (WWR decreased) or worsened (WWR increased). Again, some interesting results were observed. Water stress conditions improved for more than half of the population for most of the cases shown in Table 10. This may indicate that climate change alleviates water scarcity or an increase in mean annual runoff may improve the availability of water. These issues are further investigated in the next subsection.

\subsection{Cumulative abstraction to demand ratio}

In order to further investigate water scarcity following climate change, the CAD is used in this section. We focused on both the index itself and the water-stressed population, which is defined here as the total population living in a grid where the index falls below 0.5 (Hanasaki et al., 2008b).

Table 11 shows the projected water-stressed population. A clear relationship was observed where the stressed population increased over time and with increasing GHG emissions, i.e. climate change degraded water availability. However, as with the WWR results, the water-stressed population did not change significantly among scenarios. This is due to the same reasons we discussed in the previous subsection: regions with a strong seasonality in both water availability and use retain these features under various climate change scenarios.

Figure 8 shows the global pattern of differences in the CAD from the baseline period. In many parts of the world, 
Table 9. Global mean irrigation water withdrawal projected by the three GCMs. Baseline period (1971-2000) is $3214 \mathrm{~km}^{3} \mathrm{yr}^{-1}$.

\begin{tabular}{|c|c|c|c|c|c|c|c|c|c|}
\hline & \multicolumn{3}{|c|}{$\mathrm{RCP} 2.6$} & \multicolumn{3}{|c|}{$\mathrm{RCP} 4.5$} & \multicolumn{3}{|c|}{ RCP8.5 } \\
\hline & 2011-2040 & $2041-2070$ & $2071-2100$ & $2011-2040$ & 2041-2070 & $2071-2100$ & 2011-2040 & 2041-2070 & $2071-2100$ \\
\hline MIROC & $1.4 \%$ & $0.8 \%$ & $1.6 \%$ & $1.4 \%$ & $2.4 \%$ & $2.8 \%$ & $2.0 \%$ & $4.8 \%$ & $10.0 \%$ \\
\hline HadGEM & $0.9 \%$ & $-0.0 \%$ & $-0.2 \%$ & $0.6 \%$ & $1.7 \%$ & $1.9 \%$ & $0.9 \%$ & $2.9 \%$ & $6.7 \%$ \\
\hline GFDL & $1.8 \%$ & $2.0 \%$ & $1.1 \%$ & $2.3 \%$ & $2.3 \%$ & $2.4 \%$ & $1.7 \%$ & $3.8 \%$ & $7.1 \%$ \\
\hline
\end{tabular}
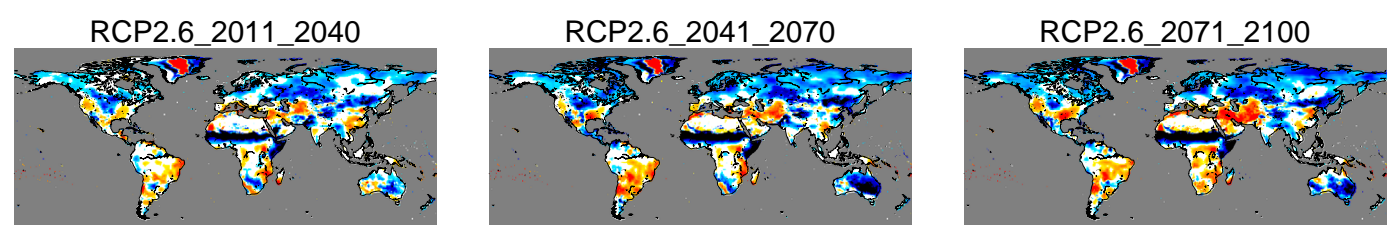

RCP4.5 2011 2040
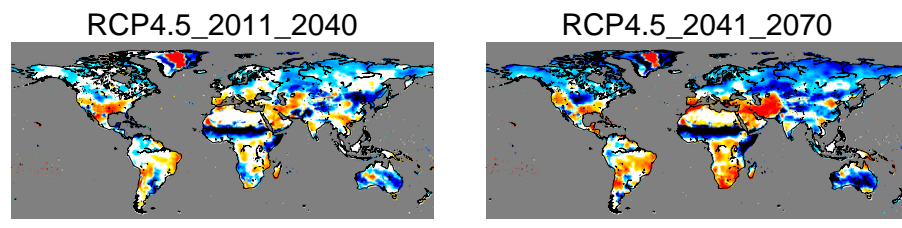

RCP8.5_2011_2040
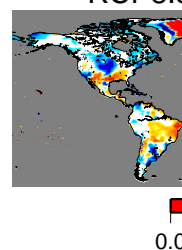

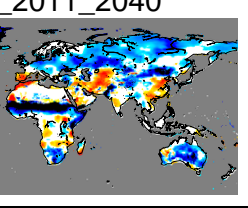

0.5
RCP8.5_2041_2070

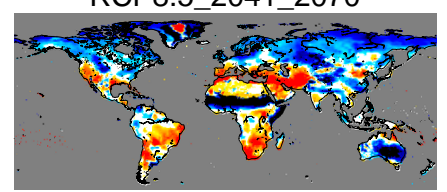

0.9

1.1

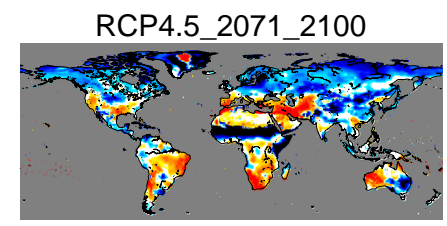

RCP8.5_2071_2100

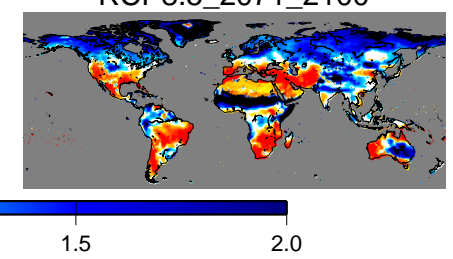

Fig. 5. Global pattern of change (ratio) in the mean annual runoff from the baseline period [-].

the water stress increased. The pattern differs from that of runoff change (Fig. 5), indicating that, although the total annual runoff increased, water resources were not available when they were needed. For example, while the mean annual runoff increased in the Sahel regions, CAD decreased (i.e. water stress increases). The increase in runoff in the wet seasons did not contribute to water resources in dry seasons, and the gap between water availability and use in dry seasons worsened. The results imply that the increase in mean annual runoff did not alleviate water scarcity in these regions.

Table 11 shows the population living in the grid cells where water stress conditions improved (CAD increased) or worsened (CAD decreased). The population suffered from an increase in water stress over time and with increased GHG emissions. Although total global runoff increased, the results indicate that less than $30 \%$ of the population benefitted in terms of improved water availability.

The results using the CAD are substantially different from those using the WWR. The WWR has been widely used in previous water resource assessments, but the results should be interpreted with caution when it is applied to climate change impact assessments. Because of the nature of the WWR, water stress is alleviated when the mean annual runoff increases. Mean annual runoff could be increased by rainfall in a rainy season or under extreme precipitation. These increases are usually difficult to utilize as water resources (Kundzewitz et al., 2007). The CAD is expressed as the accumulation of daily abstraction from rivers divided by the accumulation of daily consumption-based potential water demand. This index is useful for determining whether water is available when it is needed, taking into account the seasonality of both water availability and use. Excess water (e.g. flood water in wet seasons) is not considered to be available, which is an advantage over WWR.

\section{Results and discussion Part 2: impact of climate and socio-economic change}

This section provides the results of the global water scarcity assessment regarding the response to climate and socioeconomic change.

In this section, we analyze the results of the HUM-BAU and HUM-Policy simulations in contrast with the HUMBaseline simulation. We mainly focused on the relationship between the SSPs and water scarcity. Water scarcity is 

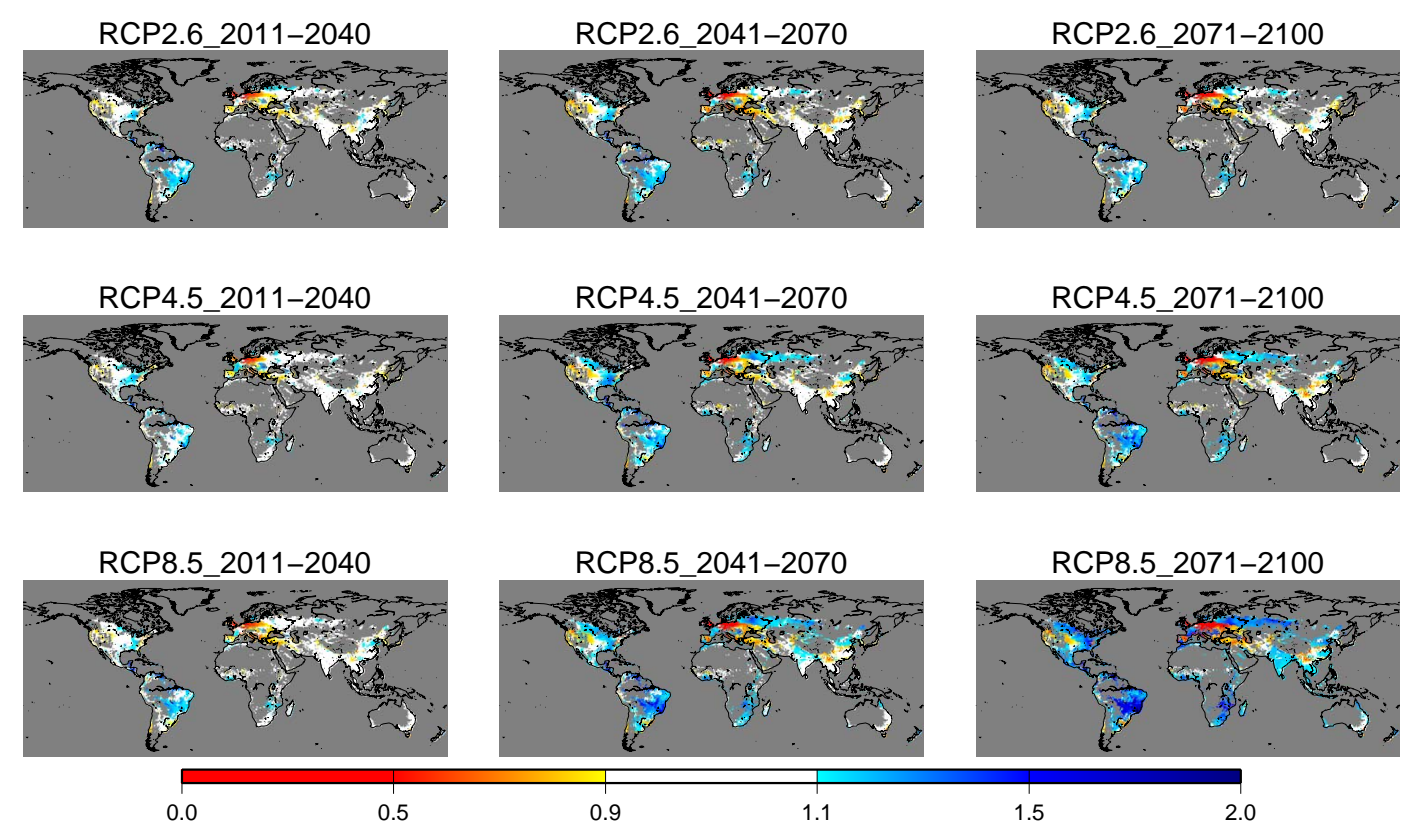

Fig. 6. Global pattern of change (ratio) in the mean annual withdrawal-based irrigation water demand from the baseline period [-].

Table 10. Global total population living under the condition of WWR $\geq 0.4$, living where the index improved (WWR decreased), and living where the index worsened (WWR increased) $\left(\times 10^{6}\right.$ person). See text for the caveats used when interpreting if the index improved/worsened. The number in brackets is the percentage of the global total population. Baseline period (1971-2000) is $1716 \times 10^{6}$ person.

\begin{tabular}{|c|c|c|c|c|c|c|c|c|c|c|}
\hline & & \multicolumn{3}{|c|}{ RCP2.6 } & \multicolumn{3}{|c|}{$\mathrm{RCP} 4.5$} & \multicolumn{3}{|c|}{ RCP8.5 } \\
\hline & & $2011-2040$ & $2041-2070$ & $2071-2100$ & $2011-2040$ & 2041-2070 & $2071-2100$ & $2011-2040$ & $2041-2070$ & 2071-2100 \\
\hline \multirow[t]{3}{*}{ MIROC } & Stressed & 1678 (27) & $1557(25)$ & $1641(27)$ & $1616(26)$ & $1612(26)$ & 1585 (26) & $1700(28)$ & $1630(26)$ & $1722(28)$ \\
\hline & Improved & $3306(54)$ & 4064 (67) & $3730(61)$ & $3652(60)$ & $3826(63)$ & $3839(63)$ & $3143(51)$ & $3544(58)$ & $3135(51)$ \\
\hline & Worsened & $2749(45)$ & $1991(32)$ & 2325 (38) & 2403 (39) & $2229(36)$ & $2217(36)$ & $2912(48)$ & $2512(41)$ & $2921(48)$ \\
\hline \multirow[t]{3}{*}{ HadGEM2 } & Stressed & 1549 (25) & 1464 (24) & 1487 (24) & $1547(25)$ & $1571(25)$ & $1522(25)$ & $1553(25)$ & $1526(25)$ & $1548(25)$ \\
\hline & Improved & 3929 (64) & $4376(72)$ & $4491(74)$ & $4151(68)$ & $3940(65)$ & $4310(71)$ & 4071 (67) & $3765(62)$ & $3811(62)$ \\
\hline & Worsened & $2126(35)$ & $1679(27)$ & $1564(25)$ & $1904(31)$ & $2115(34)$ & $1746(28)$ & $1985(32)$ & $2291(37)$ & $2244(37)$ \\
\hline \multirow[t]{3}{*}{ GFDL } & Stressed & $1725(28)$ & $1711(28)$ & 1694 (27) & $1750(28)$ & 1705 (28) & $1683(27)$ & $1674(27)$ & 1739 (28) & $1782(29)$ \\
\hline & Improved & $3080(50)$ & $3173(52)$ & $3350(55)$ & $2565(42)$ & $2822(46)$ & $3459(57)$ & $3256(53)$ & $2949(48)$ & $2742(45)$ \\
\hline & Worsened & 2975 (49) & $2883(47)$ & $2706(44)$ & $3490(57)$ & $3233(53)$ & $2596(42)$ & $2799(46)$ & $3107(51)$ & $3313(54)$ \\
\hline
\end{tabular}

assessed using the CAD. As discussed in Sects. 3.4 and 3.5, although WWR has been widely used in previous studies, it can be misleading when interpreting the impact of climate change on water scarcity. The results using the WWR are given in Appendix A, for the readers' convenience.

\subsection{Withdrawal-based potential irrigation water demand}

Table 12 shows the total global withdrawal-based potential irrigation water demand. The range among the SSPs was as much as $3154-8595 \mathrm{~km}^{3} \mathrm{yr}^{-1}$ in 2071-2100. In the HUMBAU simulation, SSP3 produced the largest withdrawalbased potential irrigation water demand, followed by SSP5, SSP2, SSP4, and SSP1. Of the three GCMs, MIROC projected the largest demand but the differences among the three
GCMs were relatively small. The HUM-Policy simulation systematically decreased the projection of withdrawal-based potential irrigation water demand in all SSPs and GCMs, as compared to the HUM-BAU simulation, but the change was only a few percent.

The differences in the results can be explained by the simulation settings summarized in Table 5. Irrigation growth scenarios and irrigation water efficiency scenarios have an important role in projecting withdrawal-based potential irrigation water demand. It is clear that the combination of low growth and high efficiency (SSP1) resulted in the least demand, and high growth and low efficiency (SSP3) resulted in the greatest demand, with the mid-growth and mid-efficiency scenario (SSP2) producing intermediate levels of demand. The setting of SSP4 is similar to SSP1, except for the irrigation efficiency scenario. SSP4 assumes that irrigation 

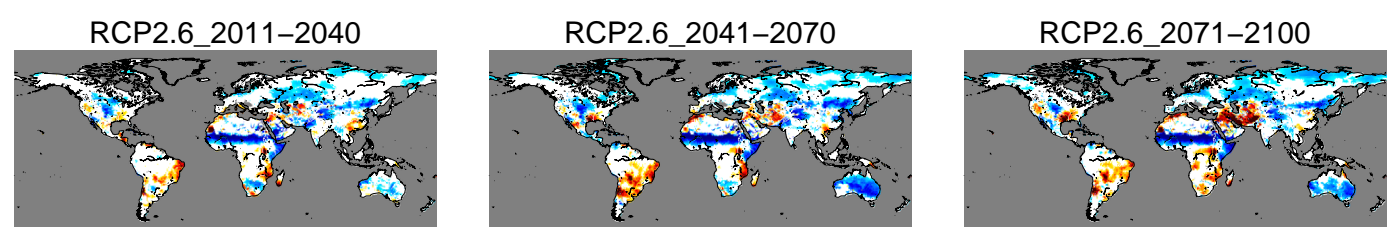

RCP4.5_2011-2040
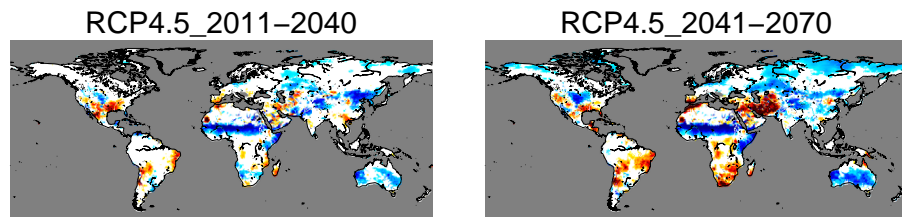

RCP8.5_2041-2070

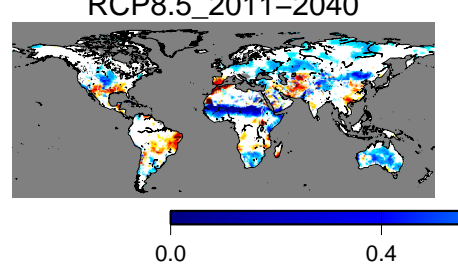

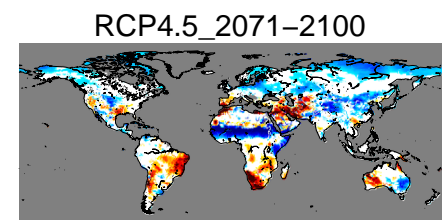

RCP8.5_2071-2100

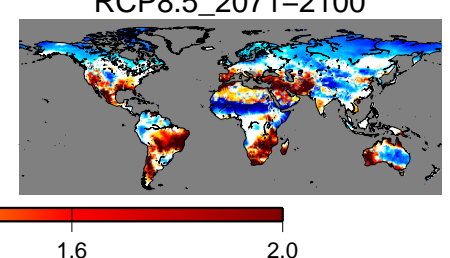

Fig. 7. Global pattern of change (ratio) in the Withdrawal to Water Resources ratio from the baseline period [-].

Table 11. Global total population living under the condition of $C A D \leq 0.5$, living where the index improved (CAD increased), and living where the index worsened (CAD decreased) $\left(\times 10^{6}\right.$ person). The number in brackets is the percentage of the global total population. Baseline period (1971-2000) is $2147 \times 10^{6}$ person.

\begin{tabular}{|c|c|c|c|c|c|c|c|c|c|c|}
\hline & & \multicolumn{3}{|c|}{ RCP2.6 } & \multicolumn{3}{|c|}{ RCP4.5 } & \multicolumn{3}{|c|}{ RCP8.5 } \\
\hline & & 2011-2040 & 2041-2070 & $2071-2100$ & 2011-2040 & 2041-2070 & $2071-2100$ & $2011-2040$ & $2041-2070$ & $2071-2100$ \\
\hline \multirow[t]{3}{*}{ MIROC } & Stressed & $2230(36)$ & $2248(37)$ & $2262(37)$ & $2245(37)$ & 2278 & $2281(37)$ & $2269(37)$ & $2346(38)$ & $2529(41)$ \\
\hline & Improved & $1853(30)$ & 1809 (29) & $1771(29)$ & $1936(31)$ & $1663(27)$ & $1613(26)$ & 1791 (29) & $1390(22)$ & $1073(17)$ \\
\hline & Worsened & $4202(69)$ & $4247(70)$ & $4285(70)$ & $4119(68)$ & 4392 (72) & 4443 (73) & $4265(70)$ & 4665 (77) & $4983(82)$ \\
\hline \multirow[t]{3}{*}{ HadGEM2 } & Stressed & 2388 (39) & $2416(39)$ & 2405 (39) & 2384 (39) & $2447(40)$ & $2491(41)$ & 2406 (39) & $2500(41)$ & $2627(43)$ \\
\hline & Improved & 1127 (18) & $1182(19)$ & $1244(20)$ & $1146(18)$ & 1075 (17) & $1072(17)$ & $1062(17)$ & $1093(18)$ & $1043(17)$ \\
\hline & Worsened & $4928(81)$ & $4873(80)$ & $4812(79)$ & $4910(81)$ & $4981(82)$ & $4983(82)$ & 4994 (82) & $4962(81)$ & $5012(82)$ \\
\hline \multirow[t]{3}{*}{ GFDL } & Stressed & $2248(37)$ & 2239 (36) & 2224 (36) & $2254(37)$ & $2271(37)$ & $2292(37)$ & $2266(37)$ & $2294(37)$ & 2412 (39) \\
\hline & Improved & $1947(32)$ & $1832(30)$ & 1961 (32) & 1784 (29) & $1550(25)$ & $1593(26)$ & $1720(28)$ & $1512(24)$ & $1296(21)$ \\
\hline & Worsened & 4108 (67) & $4223(69)$ & 4094 (67) & $4271(70)$ & 4505 (74) & $4462(73)$ & $4336(71)$ & $4543(75)$ & 4759 (78) \\
\hline
\end{tabular}

efficiency is high in OECD countries and low in non-OECD countries. Because the irrigation-equipped area is predominantly located in non-OECD countries, this assumption contributes to the increased withdrawal-based potential irrigation water demand when using SSP4, as compared to SSP1. Similarly, the irrigation growth in SSP5 was identical to that of SSP3 but, due to improvements in efficiency, the increase in potential water demand for SSP5 was much more restricted than for SSP3. In addition to the irrigation growth and efficiency scenarios, the climate scenarios are also different for each SSP. However, as discussed in the previous chapter and as shown in Table 9, the effect produced a difference of only few percent at most. This also explains why the differences in the HUM-BAU and HUM-Policy simulations were small.
Table 13 shows the total global potential water withdrawal demand for all sectors. We added the global withdrawalbased potential irrigation (Table 12) and industrial and municipal water demands (Tables 10 and 11 of Hanasaki et al., 2013). As with the global irrigation water withdrawal, SSP3 produced the largest demand, followed by SSP5, SSP2, SSP4, and SSP1. SSP3 produced levels of demand two and three times higher than SSP1 in 2041-2070 and 2071-2100, respectively.

Figure 9 shows the geographical pattern of change in withdrawal-based potential irrigation water demand. For SSP1, water demand displayed only small changes and even decreased in some regions of the Northern Hemisphere. For SSP4, which assumes low irrigation water use efficiency in non-OECD countries, the potential irrigation water demand increased in those countries. For SSP2 and SSP3, the 

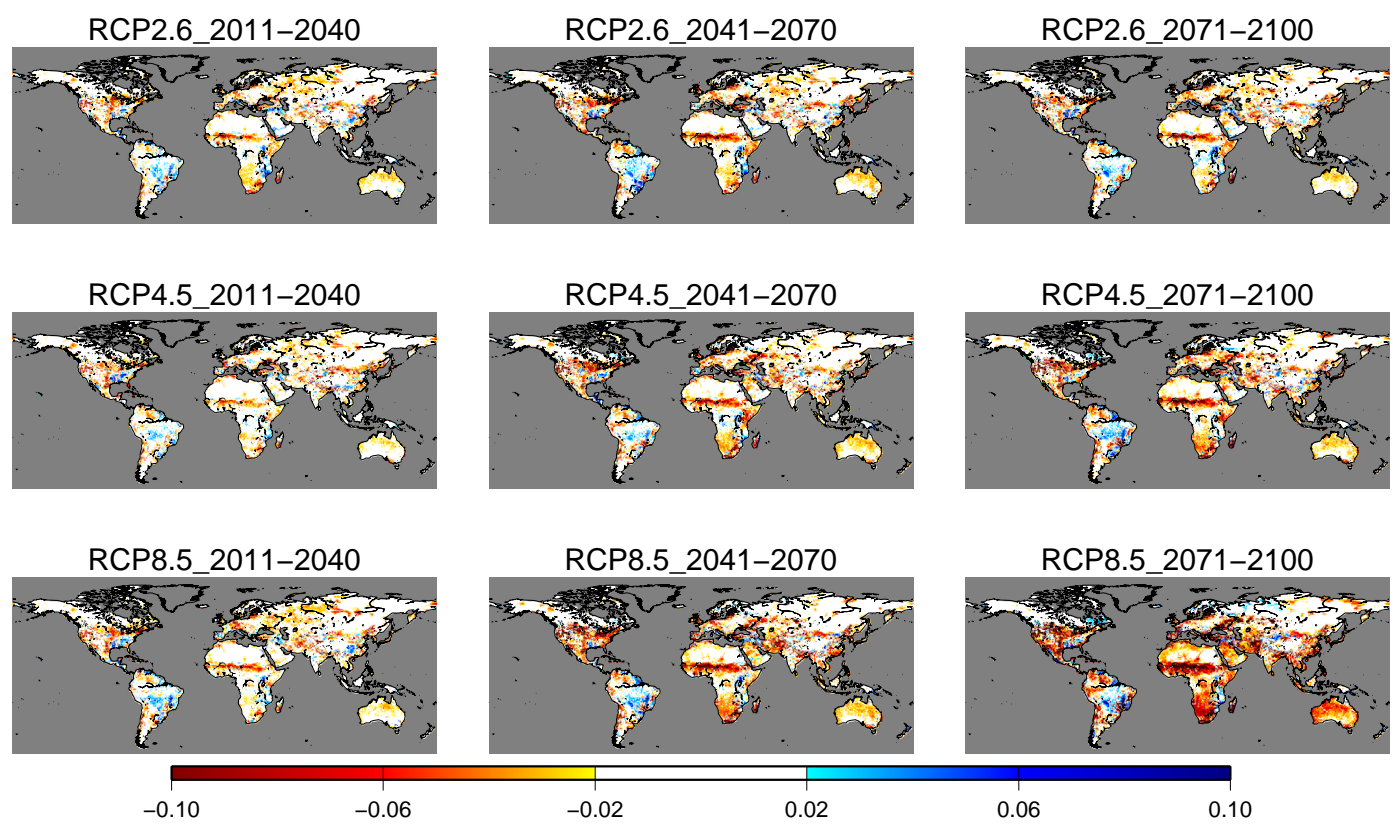

Fig. 8. Global pattern of change (difference) in the Cumulative Abstraction to Demand ratio from the baseline period [-].

Table 12. Total global irrigation water withdrawal projected from three GCMs $\left[\mathrm{km}^{3} \mathrm{yr}^{-1}\right]$. Note that the baseline is $3214 \mathrm{~km}^{3} \mathrm{yr}^{-1}$.

\begin{tabular}{|c|c|c|c|c|c|c|c|c|c|c|c|}
\hline & & \multicolumn{2}{|c|}{ SSP1 } & \multicolumn{2}{|c|}{ SSP2 } & \multicolumn{2}{|c|}{ SSP3 } & \multicolumn{2}{|c|}{ SSP4 } & \multicolumn{2}{|c|}{ SSP5 } \\
\hline & & $2041-2070$ & $2071-2100$ & $2041-2070$ & $2071-2100$ & $2041-2070$ & $2071-2100$ & $2041-2070$ & $2071-2100$ & $2041-2070$ & $2071-2100$ \\
\hline \multirow[t]{2}{*}{ MIROC } & BAU & 3204 & 3208 & 4175 & 4921 & 6091 & 8595 & 3781 & 4139 & 5162 & 6663 \\
\hline & Policy & 3137 & 3112 & 4077 & 4599 & 5986 & 8173 & 3702 & 4015 & 5073 & 6336 \\
\hline \multirow[t]{2}{*}{ HadGEM2 } & BAU & 3170 & 3154 & 4105 & 4782 & 5994 & 8361 & 3663 & 3946 & 5079 & 6481 \\
\hline & Policy & 3114 & 3059 & 4053 & 4562 & 5924 & 8043 & 3597 & 3826 & 5020 & 6235 \\
\hline \multirow[t]{2}{*}{ GFDL } & BAU & 3210 & 3185 & 4132 & 4783 & 6026 & 8347 & 3708 & 3984 & 5106 & 6470 \\
\hline & Policy & 3169 & 3093 & 4071 & 4568 & 5981 & 8095 & 3662 & 3868 & 5068 & 6275 \\
\hline
\end{tabular}

potential water demand for most regions increased, particularly in South Asia and Eastern South America.

\subsection{Water scarcity assessment using the Cumulative Abstraction to Demand (CAD) ratio}

Table 14 shows the water-stressed population using the CAD. The water-stressed population was largest for SSP3, followed by SSP2, SSP5, SSP4, and SSP1. Taking into account the differences of population, the percentage of the total global population that is projected to become water stressed was largest for SSP3, followed by SSP5, SSP2, SSP4, and SSP1. This order is identical to that observed for the total potential water demand (Table 13).

For SSP1, even though the total withdrawal-based potential water demand was smaller than the baseline period, the index worsened for more than $74 \%$ of the global population in both the HUM-BAU and HUM-Policy simulations. This can be explained by the two key factors of climate change and population growth. First, as already shown in Table 11, climate change degraded the water availability of more than
$67 \%$ of the global population. Moreover, the increase in population further increased the water-stressed population, negating the impact of a decrease in total potential water demand (Table 13).

The range in the size of water-stressed populations among SSPs that took both water use and climate scenarios into account (Table 14) was much greater than that of the HUM-Fix simulation, which only took a climate scenario into account (Table 11). This indicates that a water-stressed population is much more sensitive to a water use (or socio-economic) scenario than climate change. Note that the water-stressed population increased in all scenarios, including SSP1 in which total global potential water demand decreases. This is mainly because of the increase in population, particularly in developing countries.

Figure 10 shows the geographical pattern of differences in the CAD. It is clear that in all SSPs water stress conditions increase in the Sahel and southern Africa. This is due to the increase in consumption-based potential water demand from all sectors. Substantial growth in electricity production and population has led to an increase in industrial and municipal 
Table 13. Total global withdrawal-based potential water demand projected by three GCMs $\left[\mathrm{km}^{3} \mathrm{yr}^{-1}\right]$. Figures are a summation of irrigation water (shown in Table 12) and industrial and municipal water (Hanasaki et al., 2013). Note that the baseline is $4242 \mathrm{~km}^{3} \mathrm{yr}^{-1}$.

\begin{tabular}{|c|c|c|c|c|c|c|c|c|c|c|c|}
\hline & & \multicolumn{2}{|c|}{ SSP1 } & \multicolumn{2}{|c|}{ SSP2 } & \multicolumn{2}{|c|}{ SSP3 } & \multicolumn{2}{|c|}{ SSP4 } & \multicolumn{2}{|c|}{ SSP5 } \\
\hline & & $2041-2070$ & $2071-2100$ & $2041-2070$ & $2071-2100$ & $2041-2070$ & $2071-2100$ & $2041-2070$ & $2071-2100$ & $2041-2070$ & $2071-2100$ \\
\hline \multirow[t]{2}{*}{ MIROC } & BAU & 4295 & 3977 & 6369 & 7077 & 8827 & 11456 & 5618 & 5893 & 6535 & 7700 \\
\hline & Policy & 4229 & 3883 & 6272 & 6760 & 8723 & 11041 & 5540 & 5771 & 6447 & 7378 \\
\hline \multirow[t]{2}{*}{ HadGEM2 } & BAU & 4261 & 3924 & 6300 & 6939 & 8730 & 11222 & 5510 & 5715 & 6453 & 7519 \\
\hline & Policy & 4206 & 3830 & 6248 & 6723 & 8661 & 10911 & 5445 & 5597 & 6395 & 7277 \\
\hline \multirow[t]{2}{*}{ GFDL } & BAU & 4300 & 3954 & 6327 & 6942 & 8762 & 11212 & 5554 & 5754 & 6480 & 7510 \\
\hline & Policy & 4261 & 3864 & 6266 & 6730 & 8717 & 10963 & 5509 & 5639 & 6443 & 7318 \\
\hline
\end{tabular}

Table 14. Global total population living in grid cells where the CAD $<0.5\left(\times 10^{6}\right.$ person). The number in brackets is the percentage of total population.

\begin{tabular}{|c|c|c|c|c|c|c|c|c|c|c|c|c|}
\hline & & & \multicolumn{2}{|c|}{ SSP1 } & \multicolumn{2}{|c|}{ SSP2 } & \multicolumn{2}{|c|}{ SSP3 } & \multicolumn{2}{|c|}{ SSP4 } & \multicolumn{2}{|c|}{ SSP5 } \\
\hline & & & $2041-2070$ & $2071-2100$ & $2041-2070$ & $2071-2100$ & $2041-2070$ & $2071-2100$ & 2041-2070 & $2071-2100$ & 2041-2070 & $2071-2100$ \\
\hline \multirow[t]{6}{*}{ MIROC } & \multirow[t]{3}{*}{ BAU } & Stressed & $2853(39)$ & 2588 (39) & $3642(43)$ & $4117(48)$ & $4265(48)$ & $5503(54)$ & 3149 (39) & $3427(40)$ & $3333(45)$ & $3284(48)$ \\
\hline & & Improved & $1645(22)$ & $1343(20)$ & 1053 (12) & 749 (8) & $796(9)$ & $560(5)$ & $1654(20)$ & 1367 (16) & 904 (12) & $715(10)$ \\
\hline & & Worsened & $5573(77)$ & $5169(79)$ & 7249 (87) & 7798 (91) & $7963(90)$ & $9532(94)$ & $6260(79)$ & $6998(83)$ & $6428(87)$ & $6098(89)$ \\
\hline & \multirow[t]{3}{*}{ Policy } & Stressed & $2804(38)$ & $2498(38)$ & 3519 (42) & $3782(44)$ & $4106(46)$ & $5197(51)$ & 3113 (39) & 3323 (39) & $3215(43)$ & $3116(45)$ \\
\hline & & Improved & $1810(25)$ & 1577 (24) & 1204 (14) & 949 (11) & $879(10)$ & $664(6)$ & $1770(22)$ & $1578(18)$ & $973(13)$ & $796(11)$ \\
\hline & & Worsened & $5409(74)$ & 4935 (75) & $7098(85)$ & 7598 (88) & $7880(89)$ & 9428 (93) & 6144 (77) & $6787(81)$ & $6359(86)$ & 6017 (88) \\
\hline \multirow[t]{6}{*}{ HadGEM2 } & \multirow[t]{3}{*}{$\mathrm{BAU}$} & Stressed & 3046 (42) & 2793 (42) & $3816(45)$ & $4298(50)$ & $4434(50)$ & $5643(55)$ & $3378(42)$ & $3786(45)$ & 3489 (47) & 3379 (49) \\
\hline & & Improved & 1379 (19) & $1225(18)$ & 977 (11) & $832(9)$ & $793(9)$ & $679(6)$ & $1371(17)$ & $1182(14)$ & $920(12)$ & 785 (11) \\
\hline & & Worsened & $5839(80)$ & $5287(81)$ & $7326(88)$ & $7716(90)$ & $7966(90)$ & 9413 (93) & $6543(82)$ & $7182(85)$ & $6413(87)$ & $6027(88)$ \\
\hline & \multirow[t]{3}{*}{ Policy } & Stressed & 3009 (41) & $2685(41)$ & 3754 (45) & $4056(47)$ & 4362 (49) & $5476(54)$ & $3344(42)$ & 3613 (43) & 3414 (46) & $3260(47)$ \\
\hline & & Improved & $1446(20)$ & $1377(21)$ & 964 (11) & $841(9)$ & $846(9)$ & $720(7)$ & 1473 (18) & 1375 (16) & 992 (13) & 900 (13) \\
\hline & & Worsened & $5772(79)$ & $5135(78)$ & $7338(88)$ & $7706(90)$ & $7912(90)$ & $9372(92)$ & $6441(81)$ & $6990(83)$ & $6340(86)$ & $5913(86)$ \\
\hline \multirow[t]{6}{*}{ GFDL } & \multirow[t]{3}{*}{ BAU } & Stressed & 2834 (39) & $2596(39)$ & 3567 (42) & $3966(46)$ & 4188 (47) & $5334(52)$ & 3164 (39) & 3474 (41) & $3270(44)$ & $3164(46)$ \\
\hline & & Improved & $1660(22)$ & $1384(21)$ & 999 (12) & $903(10)$ & $776(8)$ & $802(7)$ & $1591(20)$ & $1336(15)$ & $953(12)$ & $882(12)$ \\
\hline & & Worsened & $5558(76)$ & $5128(78)$ & 7304 (87) & $7644(89)$ & $7982(91)$ & $9290(92)$ & $6323(79)$ & $7028(84)$ & $6379(86)$ & $5931(87)$ \\
\hline & \multirow[t]{3}{*}{ Policy } & Stressed & $2805(38)$ & 2470 (37) & $3512(42)$ & $3750(43)$ & 4131 (47) & $5179(51)$ & 3105 (39) & 3295 (39) & $3233(44)$ & 3058 (44) \\
\hline & & Improved & 1737 (24) & 1664 (25) & $1046(12)$ & $869(10)$ & $746(8)$ & 712 (7) & $1713(21)$ & 1592 (19) & 995 (13) & 899 (13) \\
\hline & & Worsened & $5482(75)$ & $4848(74)$ & $7256(87)$ & 7678 (89) & $8013(91)$ & $9380(92)$ & $6202(78)$ & $6773(80)$ & $6337(86)$ & $5914(86)$ \\
\hline
\end{tabular}

water demands. For SSP1, the water availability of other regions was less severely affected. The situation is similar in SSP4. In contrast, for SSP2 and SSP3, water stress conditions increase in populated areas such as northern to central China, the Mediterranean, and eastern to central North America.

The geographical pattern of Fig. 10 can be explained by the change in the CAD influenced by the different climate scenarios (Fig. 8) and water use reflecting different socioeconomic scenarios (Fig. 9). For SSP1, because water use is not increasing significantly at the global level, the results are similar to Fig. 8 except Africa. In contrast, for SSP3, a significant increase in water use resulted, which produced a different pattern to Fig. 8.

Figure 11 shows the population living in grid cells where $\mathrm{CAD}<0.5$ for regions of the Asia-Pacific Integrated Model (AIM)-SSP. AIM-SSP subdivides the world into 12 regions (Africa, Middle East, Latin America, North America, Rest of Asia, India, China, Oceania, Japan, EU, Rest of Europe including the Baltic countries, and Former Soviet Union excluding the Baltic countries). The number of water-stressed populations in the last five regions is merged in Fig. 11, because each number was small compared to the other regions. Water-stressed regions are unevenly distributed in the world. The number of water-stressed populations was highest in Africa, India, China, and Rest of Asia throughout the century. The largest growth in water-stressed populations was seen in Africa.

Figure 12 shows the percentage of the global population in specific water stress categories. We subdivided the population of the world according to two factors. First, all grid cells were subdivided into three according to the change in CAD ( $\triangle \mathrm{CAD})$. We used the term Significant Degradation for grid cells where $\triangle \mathrm{CAD}<-0.05$, Moderate Degradation where $-0.05 \leq \triangle \mathrm{CAD}<0$, and Alleviation or no change where $0 \leq \Delta$ CAD. Second, each category was further subdivided into three by the CAD. We used the term Highly Stressed for $\mathrm{CAD}<0.5$, Moderately Stressed for $0.5 \leq \mathrm{CAD}<0.8$, and Less Stressed for $0.8 \leq \mathrm{CAD}$. The results clearly showed that an alleviation of water stress conditions were projected for only a limited proportion of the global population, (i.e. CAD decreases compared with baseline period, shown in blue) in all of the SSPs. For most people in the world, water stress conditions increase due to global climate change (red and orange). However, populations suffering from severe degradation of the CAD $(\triangle \mathrm{CAD}<-0.05)$ vary among the scenarios. For example, in SSP1 around $30 \%$ of the global population 


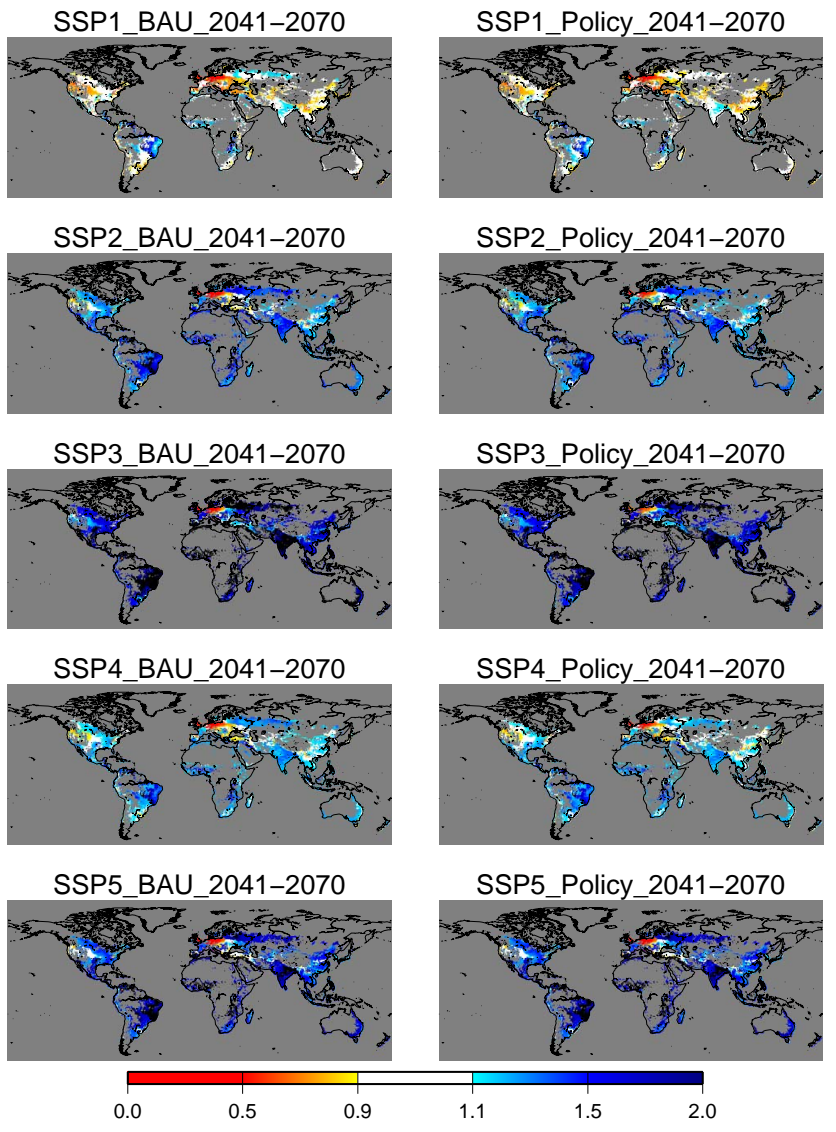

Fig. 9. Global pattern of change (ratio) in the withdrawal-based potential irrigation water demand of SSP1-5 from the baseline period $[-]$.

suffer from severe degradation (shown as red), whereas for SSP3 the value is around $60 \%$ in 2041-2070. Fewer populations suffered from severe water scarcity when a climate policy was taken into consideration, especially in 2071-2100.

\subsection{Implications}

Based on the findings above, particularly from Figs. 11 and 12 , we derived the implications of each SSP.

SSP1 (Sustainability) depicts a future world based on sustainable practices. For this scenario, we combined the best available scenarios and options in terms of the least climate change and the smallest increase in water use. For example, we adopted RCP 2.6 as a climate scenario with the adoption of a climate policy that was intended to stabilize the global mean air temperature around $+2{ }^{\circ} \mathrm{C}$ from the industrial revolution level. For the water use scenario, we adopted the lowest projection of irrigated area expansion from published reports $\left(+0.06 \% \mathrm{yr}^{-1}\right.$; see Table 5 and Table 5 of Hanasaki et al., 2013) and the highest rate of improvement in irrigation water use efficiency, to make it compatible with the key concepts of SSP1. The efficiency improvement of industrial water use was taken from the observed rates in highly water-

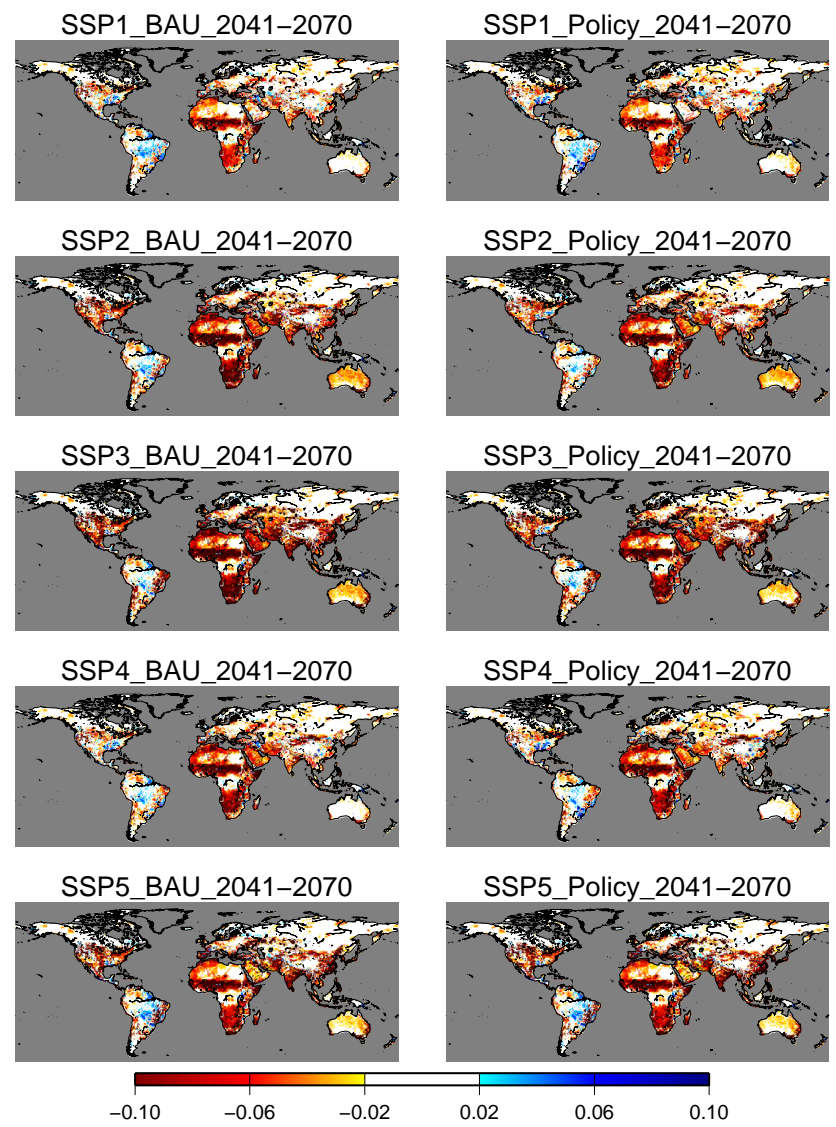

Fig. 10. Global pattern of difference (future - baseline) in the $\mathrm{Cu}$ mulative Abstraction to Demand ratio of SSP1-5 from the baseline period $[-]$.

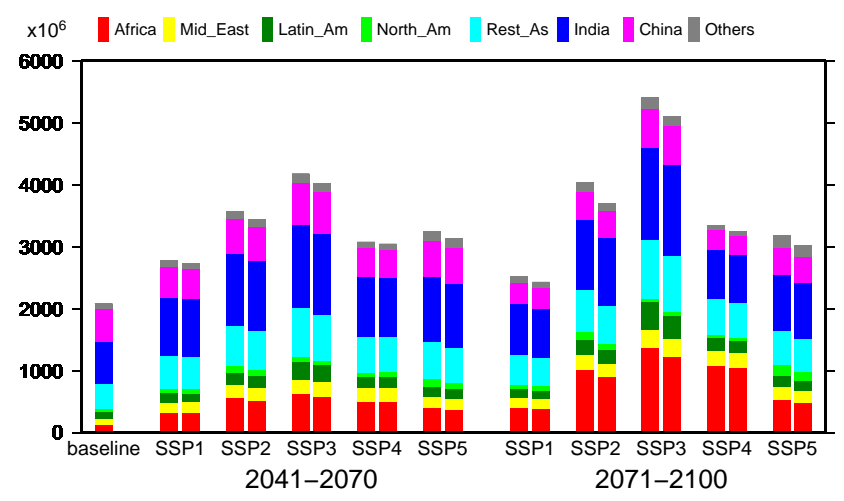

Fig. 11. Region-wise total global population living in grid cells where $\mathrm{CAD}<0.5$. The bars on the left and right show the results of HUM-BAU (no climate policy) and HUM-Policy (with climate policy), respectively.

efficient countries in the latter half of the 20th century. Municipal water withdrawal decreased toward a per capita municipal water use of $200 \mathrm{~L} \mathrm{day}^{-1}$ globally. Consequently, the projected total water withdrawal decreased slightly, as compared to the baseline period. Although the resulting water 


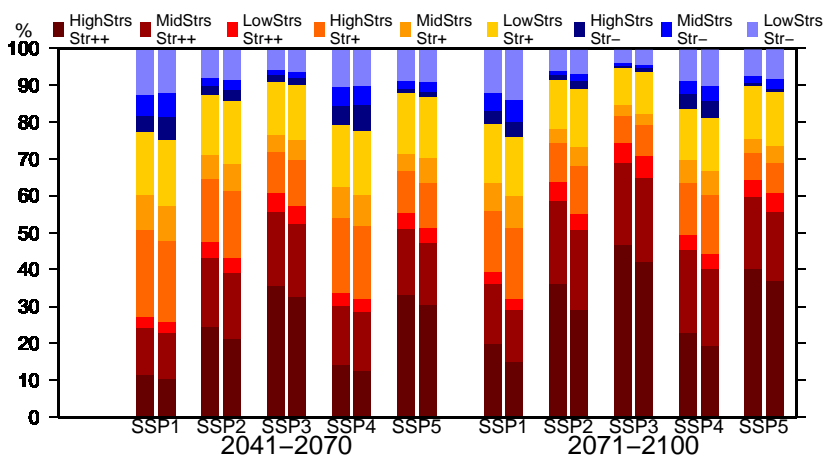

Fig. 12. Percentage of global population living in grid cells categorized as Significant Degradation $(\triangle \mathrm{CAD}<-0.05$, red), Moderate Degradation $(-0.05 \leq \triangle \mathrm{CAD}<0$, orange), and Alleviation or no change $(0 \leq \triangle \mathrm{CAD}$, blue). Each category was subdivided into three by the change in the CAD recorded as Highly Stressed $(\mathrm{CAD}<0.5$, dark), Moderately Stressed $(0.5 \leq \mathrm{CAD}<0.8$, medium), and Less Stressed $(0.8 \leq \mathrm{CAD}$, pale). The bars on the left and right show the results of HUM-BAU (no climate policy) and HUM-Policy (with climate policy), respectively.

scarcity was by far the lowest among the SSPs, the results indicated that global water scarcity in SSP1 increased, as compared to the baseline period. This implies that even for one of the most optimistic scenario combinations, pressure on water resources will continue throughout the current century.

SSP2 (Middle of the Road) depicts a future world where the socio-economic trends of recent decades continue. For this scenario we combined moderate scenarios and options. We confirmed that our projected water withdrawal largely agreed with earlier reports that assumed the continuation of current trends (Hanasaki et al., 2013). This is consistent with the key concept of SSP2, which is a future world considered to be "dynamic as usual". Under these assumptions, water use continuously increased and consequently water stress also increased in many parts of the world. Figure 11 indicates that the total global water-stressed population nearly doubled by the middle of the century and continued to increase toward the end of the century.

SSP3 (Fragmented World) depicts a future world of extreme poverty and a rapidly growing population, which makes it difficult to adapt to climate change. For this scenario, we combined the high-end scenarios and options that were available. Water use is substantially increased globally mainly due to the expansion of irrigated area and low water use efficiency. Under this scenario, the total withdrawalbased potential water demand grew considerably, doubling by 2041-2070, and tripling by 2071-2100. Consequently, the total global water-stressed population had nearly tripled by the end of the century. About $50 \%$ of the total population was projected to live in grid cells categorized as Highly Stressed $(0.5<\mathrm{CAD})$ and Significant Degradation $(\triangle \mathrm{CAD}<-0.05$; Fig. 12 in 2071-2100).
SSP4 (Inequality) depicts a highly unequal future world. The water use scenario was similar to that of SSP1, but the improvements in efficiency were assumed to be low for nonOECD countries. The results showed similar water stress characteristics to SSP1, but much more severe for developing countries, particularly in Africa (Fig. 11).

SSP5 (Conventional Development) depicts a future world of robust economic growth based on the continued exploitation of fossil fuels. Its water use scenario was similar to that of SSP3, but the improvement in efficiency was high for all countries, as inferred from the narrative scenario of SSP5. Together with the lower population growth, the waterstressed population was lower than in SSP3, but the proportion of the global population suffering from reduced water availability was almost the same as in SSP3. This implied that social activity could be restricted by water shortages, which contradicted the qualitative scenario of SSP5 that indicated fast and robust economic growth. This implied the need for the development of extra water resources, such as increasing water storage capacity, abstracting more groundwater or increasing desalination.

\section{Uncertainty}

\subsection{Climate scenario}

In this study, we used three GCMs, although more than 40 GCMs are readily available (Taylor et al., 2012). There is a need to increase the number of GCMs in order to cover the uncertainty of climate projections. We selected three GCMs subjectively. Although there is no established methodology to prioritize the available GCMs (Knutti et al., 2010), performance metrics for GCMs (e.g. Gleckler et al., 2008) would be useful to ensure that the selection process is less subjective.

When preparing the climate scenario, we adopted a shifting and scaling method (Lehner et al., 2006) to remove the biases of the GCMs. This was computationally efficient, because only the mean monthly difference was added or multiplied to the retrospective time series of meteorological forcing data. Moreover, because of this simplicity, the climate scenario is consistent with the baseline period, and produces stable results. However, neglecting the temporal variability of change is a widely recognized shortcoming of this method. In some cases, this might underestimate (or overestimate) the risk of drought and water shortage. New techniques of GCM bias correction have been devised and have been applied in global studies. For example, Piani et al. (2010) developed a global daily climate scenario for three CMIP3 GCMs. Although it is very labor intensive to develop such techniques, their adoption is essential. 


\subsection{Socio-economic and water use scenario}

Because the uncertainty associated with the socio-economic and water use scenario is described in the accompanying paper (Hanasaki et al., 2013), we only summarize the key points here. First, we used AIM-SSP, which provides preparatory quantitative scenarios for the SSPs from an integrated assessment by the Asia-Pacific Integrated Model (Kainuma et al., 2002). Official SSP products will be released in the near future, and may vary from the current AIM-SSP. Second, the irrigation scenario was developed from a literature review that was independent of any food-related SSP factors. An integrated model that links crops, water, and land (e.g. LotzeCampen et al., 2008) is likely to establish a more comprehensive and consistent scenario. Third, potential irrigation water demand was estimated in a highly conceptualized way. The effect of $\mathrm{CO}_{2}$ fertilization would influence water demand (e.g. Gerten et al., 2011), but this process was not included in this study. Local irrigation practices (e.g. timing, duration) were not fully reflected in the model. Fourth, we used a simplistic model to estimate industrial and municipal water use. Progress in this area of modeling has long been obstructed by a lack of data, but further efforts are needed. The results of water resource assessments clearly show that the water use scenario that is used significantly affects the results; hence further efforts are needed to establish consistent scenarios.

\subsection{Combination of scenarios}

In this study, many independent scenarios were combined, namely the SSPs (socio-economic scenarios), our water use scenario (Hanasaki et al., 2013), RCPs (GHG emission scenario) and CMIP5 (climate scenario). This allowed us to achieve our primary objective, i.e. to develop a water use scenario compatible with the SSPs for use in global water scarcity assessments. Here two points should be noted. First, because each scenario was independently developed, consistency among the scenarios was unachievable. Combinations of scenarios and options were decided on a largely arbitrary basis, because there were neither clear guidelines nor many previous studies that were available. To improve consistency, further interdisciplinary modeling efforts are needed to develop an integrated model that incorporates all of these aspects. Second, the feasibility of each scenario could be different. For example, SSP1 and SSP3 have been developed to depict high and low-end scenarios, which might be perceived to be less realistic than the "Middle of the Road" scenario depicted in SSP2. Each scenario should be considered to be an option and not a prediction of the future.

\subsection{Models}

As described earlier, the H08 model has been applied to a number of studies and has been used in international model comparison projects. All of the results indicate that the per- formance of the model is at the current state-of-the-art level. However, it should be noted that the basin and grid-cell level results include uncertainties because basin-wise fine parameter tuning has not been carried out (this is a challenging task; see Hanasaki et al., 2008a for detailed discussion). In addition, systematic model uncertainty analysis should be carried out by, for example, including parameter sensitivity tests for major sub-models. Model inter-comparison projects for climate change simulation have been undertaken (e.g. WaterMIP; Hagemann et al., 2013; ISI-MIP; http://isi-mip.org/), and are useful for quantifying the uncertainties of each participating model.

Attention should be paid to the model configuration in this study. As shown in Fig. 1, we assumed that all water is abstracted from rivers. Only reservoirs that have more than $1.0 \times 10^{9} \mathrm{~m}^{3}$ of storage capacity were taken into account. This assumption was useful when investigating the impact of climate change on daily water availability: the change in water balance and flow regime is directly reflected in the CAD water scarcity index. Although river water accounts for $78 \%$ of total global water withdrawal (FAO, 2011), in reality, river water is one of many sources of water. Groundwater is an important source of water, and has been reported to be vulnerable to climate change due to predicted decreases in recharge (Döll, 2009). Reservoirs with a storage capacity of less than $1.0 \times 10^{9} \mathrm{~m}^{3}$ also have an important role by storing water in wet periods and carrying it over into dry seasons. Although these are important sources of water we excluded them for two reasons. First, a scaling problem hampers the modeling. The groundwater dynamics take place at a much finer scale than the current spatial resolution of $0.5 \times 0.5^{\circ}$. Similarly, in some cases, dozens of reservoirs are located in a particular grid cell. Parameterization of these is still in its infancy (Hanasaki et al., 2010). Second, preparing scenarios for these terms is very challenging and may be impossible (i.e. it is difficult, if not impossible, to know the exact location and period of individual reservoir and irrigation projects in the future).

\subsection{Water scarcity indexes}

We mainly assessed water scarcity globally using the CAD index. The CAD directly accounts for the fulfillment of daily consumption-based potential water demand, which excludes flooding or extreme runoff from available water resources. However, two strong assumptions should be noted. First, the index assumes that all water comes from river water, because other sources of water, such as renewable groundwater and water stored in reservoirs, increases the CAD. This leads to an overestimation of water scarcity. Second, the index accounts for consumptive water use only. In reality large amounts of irrigation water are lost by percolation and evaporation during delivery. The technical potential of water abstraction is not taken into account either. Neglecting these points leads to an underestimation of water stress, and 
this process should be incorporated (e.g. Rost et al., 2008). Third, due to the formulation of the CAD, the timing, length, and magnitude of individual water scarcity events during the study period is not specified (e.g. CAD does not distinguish water scarcity caused by a single substantial event and frequent low-intensity ones). Moreover, CAD should not be directly linked to economical and societal losses or damages. Finally, the results of CAD are sensitive to its threshold of 0.5 .

\section{Conclusions}

A novel global water scarcity assessment was presented under the new set of scenarios on global change (Moss et al., 2010). The socio-economic scenarios of the SSPs depict five future situations with substantially different socio-economic conditions. This implies water use would also vary, but neither quantitative nor qualitative information regarding water use were available. We first developed water use models (Eqs. 1-5 of Hanasaki et al., 2013). Each has one parameter, and was assigned three options based on a literature review and historical records. By combining these parameters and the narrative scenario of the SSPs, we developed a water use scenario compatible with the key concepts of the SSPs. Water availability was projected using the latest global climate scenario of CMIP5, which was forced with the GHG emission scenarios of the RCPs. Global water scarcity was mainly assessed based on the CAD index. The CAD successfully identified locations with a projected water scarcity, taking into account the balance of daily water use and availability. It revealed that water availability will decline in the 21 st century for all scenarios tested. Our study demonstrated that the socio-economic scenarios and associated water use scenario dominate the impact of water scarcity in the $21 \mathrm{st}$ century. This was previously noted in some earlier studies (e.g. Vörörsmarty et al., 2000), but our study systematically and quantitatively evaluated it through a large number of simulations (five socio-economic scenarios, three periods in the 21 st century, and three GCMs).

As far as we know, this is the first comprehensive global water resource assessment using the new scenarios. One of the fundamental differences between the previous scenarios (SRES; Nakicenovic and Swart, 2000) and the new scenarios (RCPs and SSPs) is that the former fixed the combination of socio-economic and emission scenarios independently, while the latter allowed flexible combinations. This enables us to assess the challenge of mitigation and adaptation under various socio-economic conditions and climate stabilization targets. We developed a scenario matrix (i.e. a combination of climate and socio-economic scenarios), as shown in Fig. 3 of Part 1, and showed the results of the water scarcity assessment in Figs. 10-12 and Table 14 for every combination. These options might be useful for long-term climate policy making.

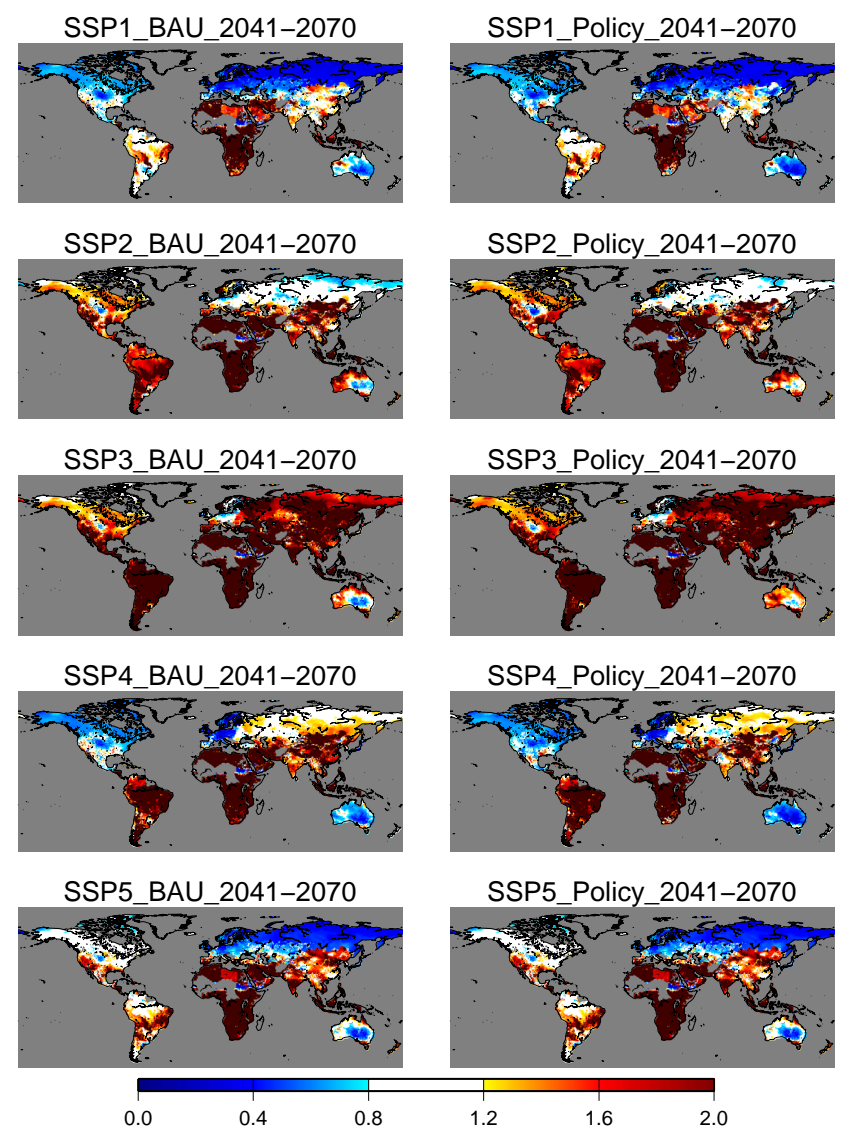

Fig. A1. Global pattern of change (ratio) in the Withdrawal to Water Resources ratio of SSP1-5 from the baseline period [-].

Our study clearly showed the importance of water use scenarios in the assessment of water scarcity. The results were particularly sensitive to an expansion of the irrigated area, the crop intensity, and improvements in the efficiency of irrigation, industrial, and municipal water use. These factors were affected by other scenarios such as population, food and nutrients, land use, industrial activity, electricity production, technological change, investment in infrastructure, development aid and many others. However, water scarcity in turn affects these factors as well: water is indispensable for all human and social activities. Further interdisciplinary work is needed for a better projection of global change and an indepth understanding of the Earth and social systems.

\section{Appendix A}

\section{Water scarcity assessment using the Withdrawal to Water Resources (WWR) ratio}

Table A1 shows the global total water-stressed population (i.e. population living in grid cells where $W / Q \geq 0.4$ ). The water-stressed population is highest for SSP3, followed by SSP2, SSP4, SSP5, and SSP1. The population in grid cells 
Table A1. Global total population living in grid cells where $0.4 \leq$ WWR $\left(\times 10^{6}\right.$ person). The number in brackets shows the percentage of total population.

\begin{tabular}{|c|c|c|c|c|c|c|c|c|c|c|c|c|}
\hline & & & \multicolumn{2}{|c|}{ SSP1 } & \multicolumn{2}{|c|}{ SSP2 } & \multicolumn{2}{|c|}{ SSP3 } & \multicolumn{2}{|c|}{ SSP4 } & \multicolumn{2}{|c|}{ SSP5 } \\
\hline & & & 2041-2070 & $2071-2100$ & 2041-2070 & $2071-2100$ & 2041-2070 & $2071-2100$ & 2041-2070 & $2071-2100$ & 2041-2070 & $2071-2100$ \\
\hline \multirow[t]{6}{*}{ MIROC } & \multirow[t]{3}{*}{ BAU } & Stressed & 2015 (27) & $1669(25)$ & $2715(32)$ & 2854 (33) & $3283(37)$ & $4006(39)$ & $2493(31)$ & $2498(29)$ & $2391(32)$ & $2258(33)$ \\
\hline & & Improved & 2164 (29) & $2932(45)$ & 777 (9) & $868(10)$ & $348(3)$ & 355 (3) & $1296(16)$ & $1311(15)$ & $1358(18)$ & $1520(22)$ \\
\hline & & Worsened & $5054(70)$ & $3580(54)$ & $7526(90)$ & 7679 (89) & $8410(96)$ & 9737 (96) & $6618(83)$ & $7053(84)$ & $5974(81)$ & $5293(77)$ \\
\hline & \multirow[t]{3}{*}{ Policy } & Stressed & $1857(25)$ & $1627(24)$ & $2696(32)$ & $2709(31)$ & 3334 (38) & $3922(38)$ & $2352(29)$ & $2430(29)$ & $2420(33)$ & 2194 (32) \\
\hline & & Improved & $2973(41)$ & $2948(45)$ & $738(8)$ & $996(11)$ & $356(4)$ & 372 (3) & $1586(20)$ & 1271 (15) & $1146(15)$ & 1654 (24) \\
\hline & & Worsened & 4245 (58) & 3565 (54) & $7565(91)$ & $7551(88)$ & $8402(95)$ & $9720(96)$ & 6328 (79) & 7093 (84) & $6186(84)$ & $5159(75)$ \\
\hline \multirow[t]{6}{*}{ HadGEM2 } & \multirow[t]{3}{*}{ BAU } & Stressed & $1875(25)$ & $1471(22)$ & $2554(30)$ & $2703(31)$ & $3129(35)$ & 3864 (38) & $2368(29)$ & $2346(28)$ & $2255(30)$ & 2055 (30) \\
\hline & & Improved & $3121(43)$ & $3728(57)$ & 1217 (14) & $1728(20)$ & $505(5)$ & $610(6)$ & 1937 (24) & 2044 (24) & 1798 (24) & $2192(32)$ \\
\hline & & Worsened & 4097 (56) & $2784(42)$ & $7085(85)$ & $6820(79)$ & $8253(94)$ & $9482(93)$ & $5977(75)$ & $6321(75)$ & $5534(75)$ & $4621(67)$ \\
\hline & \multirow[t]{3}{*}{ Policy } & Stressed & $1731(23)$ & $1462(22)$ & $2604(31)$ & $2668(31)$ & $3222(36)$ & 3727 (36) & 2207 (27) & $2312(27)$ & $2296(31)$ & $1972(28)$ \\
\hline & & Improved & 3975 (55) & 3718 (57) & 1008 (12) & 1399 (16) & $499(5)$ & $572(5)$ & 2296 (29) & 1969 (23) & 1708 (23) & 2277 (33) \\
\hline & & Worsened & 3243 (44) & $2794(42)$ & 7294 (87) & 7149 (83) & 8259 (94) & $9520(94)$ & $5618(70)$ & $6396(76)$ & $5624(76)$ & $4536(66)$ \\
\hline \multirow[t]{6}{*}{ GFDL } & \multirow[t]{3}{*}{ BAU } & Stressed & 2107 (29) & $1763(27)$ & 2855 (34) & $3016(35)$ & $3420(39)$ & $4254(42)$ & $2582(32)$ & $2693(32)$ & 2479 (33) & 2308 (33) \\
\hline & & Improved & 2114 (29) & 2487 (38) & $450(5)$ & $630(7)$ & $127(1)$ & 207 (2) & $1176(14)$ & $1067(12)$ & 985 (13) & $1419(20)$ \\
\hline & & Worsened & $5104(70)$ & $4025(61)$ & 7853 (94) & 7917 (92) & 8631 (98) & 9885 (97) & $6738(85)$ & 7298 (87) & $6347(86)$ & $5394(79)$ \\
\hline & \multirow[t]{3}{*}{ Policy } & Stressed & $2066(28)$ & $1664(25)$ & 2814 (33) & $2890(33)$ & 3377 (38) & $4148(41)$ & $2539(32)$ & $2620(31)$ & 2484 (33) & 2297 (33) \\
\hline & & Improved & $2270(31)$ & $2679(41)$ & 490 (5) & $671(7)$ & $126(1)$ & $200(1)$ & 1177 (14) & 1045 (12) & 985 (13) & 1399 (20) \\
\hline & & Worsened & $4948(68)$ & 3833 (58) & $7812(94)$ & $7876(92)$ & 8633 (98) & $9892(98)$ & $6738(85)$ & 7319 (87) & $6348(86)$ & $5414(79)$ \\
\hline
\end{tabular}

where the index improves $(W / Q$ decreased) varied between SSPs, largely reflecting the difference in population and total water withdrawal (Table 13). For SSP3, the index indicated improved water scarcity conditions for only $4 \%$ of population, while it was $29 \%$ for SSP1 in 2041-2070. Compared with the differences in the SSPs, the adoption of a climate policy had a minor effect for all scenarios, changing the values by only a few percent.

Figure A1 shows the geographical pattern of changes in the WWR. It can be seen that water stress conditions increase substantially in Africa for all scenarios. Note that this does not mean that Africa will be water stressed. As shown in Fig. 2, currently, most of the area with changes in the WWR is relatively small in Africa, because of the low levels of water use. For SSP1, the water stress conditions decrease, except for in Africa, mainly due to an increase in runoff (see Fig. 5). For SSP4, Asia and South Africa experience water stress conditions. For SSP2 and SSP3, the index suggests a decrease in water availability for almost all regions of the world, mainly due to a substantial increase in water withdrawal (Table 13).

\section{Supplementary material related to this article is available online at: http://www.hydrol-earth-syst-sci.net/ 17/2393/2013/hess-17-2393-2013-supplement.pdf.}

Acknowledgements. The authors are grateful to four anonymous reviewers for their useful comments. This research was supported by the Environment Research and Technology Development Fund (S-10 and A1103) of the Ministry of the Environment, Japan, CREST of the Japan Science and Technology Agency, and the National Institute for Environmental Studies Special Research Fund. We acknowledge the World Climate Research Programme's Working Group on Coupled Modeling, which is responsible for CMIP, and we thank the climate modeling groups (listed in Table 2 of this paper) for producing and making available their model output. For CMIP, the US Department of Energy's Program for Climate Model Diagnosis and Intercomparison provided coordinating support and led the development of software infrastructure in partnership with the Global Organization for Earth System Science Portals.

Edited by: F. Pappenberger

\section{References}

Alcamo, J., Flörke, M., and Marker, M.: Future long-term changes in global water resources driven by socio-economic and climatic changes, Hydrolog. Sci. J., 52, 247-275, 2007.

Arnell, N. W.: Climate change and global water resources, Global Environ. Change, 9, S31-S49, 1999.

Arnell, N. W.: Climate change and global water resources: SRES emissions and socio-economic scenarios, Global Environ. Change, 14, 31-52, 2004.

Döll, P.: Vulnerability to the impact of climate change on renewable groundwater resources: a global-scale assessment, Environ. Res. Lett., 4, 035006, doi:10.1088/1748-9326/4/3/035006, 2009.

Döll, P.: Impact of climate change and variability on irrigation requirements: A global perspective, Clim. Change, 54, 269-293, 2002.

Döll, P. and Siebert, S.: Global modeling of irrigation water requirements, Water Resour. Res., 38, 1037, 
doi:10.1029/2001WR000355, 2002.

Food and Agriculture Organization (FAO): AQUASTAT, available at: http://www.fao.org/nr/water/aquastat/main/index.stm (last access: 30 September 2012), 2011.

Gerten, D., Heinke, J., Hoff, H., Biemans, H., Fader, M., and Waha, K.: Global water availability and requirements for future food production, J. Hydromet., 12, 885-899, doi:10.1175/2011JHM1328.1, 2011.

Gleckler, P. J., Taylor, K. E., and Doutriaux, C.: Performance metrics for climate models, J. Geophys. Res., 113, D06104, doi:10.1029/2007JD008972, 2008.

Haddeland, I., Skaugen, T., and Lettenmaier, D. P.: Anthropogenic impacts on continental surface water fluxes, Geophys. Res. Lett., 33, L08406, doi:10.1029/2006GL026047, 2006.

Haddeland, I., Clark, D. B., Franssen, W., Ludwig, F., Voß, F., Arnell, N. W., Bertrand, N., Best, M., Folwell, S., Gerten, D., Gomes, S., Gosling, S. N., Hagemann, S., Hanasaki, N., Harding, R., Heinke, J., Kabat, P., Koirala, S., Oki, T., Polcher, J., Stacke, T., Viterbo, P., Weedon, G. P., and Yeh, P.: Multimodel Estimate of the Global Terrestrial Water Balance: Setup and First Results, J. Hydromet., 12, 869-884, doi:10.1175/2011jhm1324.1, 2011.

Hagemann, S., Chen, C., Clark, D. B., Folwell, S., Gosling, S. N., Haddeland, I., Hanasaki, N., Heinke, J., Ludwig, F., Voss, F., and Wiltshire, A. J.: Climate change impact on available water resources obtained using multiple global climate and hydrology models, Earth Syst. Dynam., 4, 129-144, doi:10.5194/esd4-129-2013, 2013.

Hanasaki, N., Kanae, S., and Oki, T.: A reservoir operation scheme for global river routing models, J. Hydrol., 327, 22-41, 2006.

Hanasaki, N., Kanae, S., Oki, T., Masuda, K., Motoya, K., Shirakawa, N., Shen, Y., and Tanaka, K.: An integrated model for the assessment of global water resources - Part 1: Model description and input meteorological forcing, Hydrol. Earth Syst. Sci., 12, 1007-1025, doi:10.5194/hess-12-1007-2008, 2008a.

Hanasaki, N., Kanae, S., Oki, T., Masuda, K., Motoya, K., Shirakawa, N., Shen, Y., and Tanaka, K.: An integrated model for the assessment of global water resources - Part 2: Applications and assessments, Hydrol. Earth Syst. Sci., 12, 1027-1037, doi:10.5194/hess-12-1027-2008, 2008 b.

Hanasaki, N., Inuzuka, T., Kanae, S., and Oki, T.: An estimation of global virtual water flow and sources of water withdrawal for major crops and livestock products using a global hydrological model, J. Hydrol., 384, 232-244, doi:10.1016/j.jhydrol.2009.09.028, 2010.

Hanasaki, N., Fujimori, S., Yamamoto, T., Yoshikawa, S., Masaki, Y., Hijioka, Y., Kainuma, M., Kanamori, Y., Masui, T., Takahashi, K., and Kanae, S.: A global water scarcity assessment under Shared Socio-economic Pathways - Part 1: Water use, Hydrol. Earth Syst. Sci., 17, 2375-2391, doi:10.5194/hess-17-23752013, 2013.

Hoekstra, A. Y., Mekonnen, M. M., Chapagain, A. K., Mathews, R. E., and Richter, B. D.: Global Monthly Water Scarcity: Blue Water Footprints versus Blue Water Availability, PLoS ONE, 7, e32688, doi:10.1371/journal.pone.0032688, 2012.

International Commission on Large Dams (ICOLD): World Register of Dams, International Commission on Large Dams, Paris, 1998.

Kainuma, M., Matsuoka, Y., and Morita, T.: Climate Policy Assessment: Asia-Pacific Integrated Modeling, Springer, Tokyo, Japan and New York, USA, 2002.

Knutti, R., Abramowitz, G., Collins, M., Eyring, V., Gleckler, P. J., Hewitson, B., and Mearns, L.: Good Practice Guidance Paper on Assessing and Combining Multi Model Climate Projections, in: Meeting Report of the Intergovernmental Panel on Climate Change Expert Meeting on Assessing and Combining Multi Model Climate Projections, edited by: Stocker, T. F., Qin, D., Plattner, G.-K., Tignor, M., and Midgley, P. M., IPCC Working Group I Technical Support Unit, University of Bern, Bern, Switzerland, 2010.

Kondo, J.: Meteorology of water environment, Asakura Publishing, Tokyo, Japan, 1994.

Kriegler, E., O’Neill, B. C., Hallegatte, S., Kram, T., Lempert, R. J., Moss, R. H., and Wilbanks, T.: The need for and use of socioeconomic scenarios for climate change analysis: A new approach based on shared socio-economic pathways, Global Environ. Change, 22, 807-822, doi:10.1016/j.gloenvcha.2012.05.005, 2012.

Krysanova, V., Wechsung, F., Arnold, J., Srinivasan, R., and Williams, J.: SWIM (Soil and Water Integrated Model) User Manual, Potsdam Institute for Climate Impact Research, Potsdam, Germany, 2000.

Kundzewicz, Z. W., Mata, L. J., Arnell, N. W., Döll, P., Kabat, P., Jiménez, B., Miller, K. A., Oki, T., Sen, Z., and Shiklomanov, I. A.: Freshwater resources and their management, in: Climate Change 2007: Impacts, Adaptation and Vulnerability. Contribution of Working Group II to the Fourth Assessment Report of the Intergovernmental Panel on Climate Change, edited by: Parry, M. L., Canziani, O. F., Palutikof, J. P., van der Linden, P. J., and Hanson, C. E., Cambridge University Press, Cambridge, UK, 173-210, 2007.

Lehner, B., Döll, P., Alcamo, J., Henrichs, T., and Kaspar, F.: Estimating the Impact of Global Change on Flood and Drought Risks in Europe: A Continental, Integrated Analysis, Climatic Change, 75, 273-299, 2006.

Lotze-Campen, H., Müller, C., Bondeau, A., Rost, S., Popp, A., and Lucht, W.: Global food demand, productivity growth, and the scarcity of land and water resources: a spatially explicit mathematical programming approach, Agr. Econom., 39, 325-338, doi:10.1111/j.1574-0862.2008.00336.x, 2008.

Monfreda, C., Ramankutty, N., and Foley, J. A.: Farming the Planet. Part 2: The Geographic Distribution of Crop Areas and Yields in the Year 2000, Global Biogeochem. Cy., 22, GB1022, doi:10.1029/2007GB002947, 2008.

Moss, R. H., Edmonds, J. A., Hibbard, K. A., Manning, M. R., Rose, S. K., van Vuuren, D. P., Carter, T. R., Emori, S., Kainuma, M., Kram, T., Meehl, G. A., Mitchell, J. F. B., Nakicenovic, N., Riahi, K., Smith, S. J., Stouffer, R. J., Thomson, A. M., Weyant, J. P., and Wilbanks, T. J.: The next generation of scenarios for climate change research and assessment, Nature, 463, 747-756, doi:10.1038/nature08823, 2010.

Nakicenovic, N. and Swart, R.: Special Report on Emissions Scenarios: A Special Report of Working Group III of the Intergovernmental Panel on Climate Change, Cambridge University Press, Cambridge, 612 pp., 2000.

Oki, T. and Kanae, S.: Global hydrological cycles and world water resources, Science, 313, 1068-1072, 2006.

Oki, T., Nishimura, T., and Dirmeyer, P.: Assessment of annual runoff from land surface models using Total Runoff Integrating 
Pathways (TRIP), J. Meteorol. Soc. Jpn., 77, 235-255, 1999.

Oki, T., Agata, Y., Kanae, S., Saruhashi, T., and Musiake, K.: Global Water Resources Assessment under Climatic Change in 2050 using TRIP, IAHS Publication, 280, 124-133, 2003.

Piani, C., Weedon, G. P., Best, M., Gomes, S. M., Viterbo, P., Hagemann, S., and Haerter, J. O.: Statistical bias correction of global simulated daily precipitation and temperature for the application of hydrological models, J. Hydrol., 395, 199-215, 2010.

Ramankutty, N., Evan, A., Monfreda, C., and Foley, J. A.: Farming the Planet. Part 1: The Geographic Distribution of Global Agricultural Lands in the Year 2000, Global Biogeochem. Cy., 22, GB1003, doi:10.1029/2007GB002952, 2008.

Raskin, P., Gleick, P., Kirshen, P., Pontius, G., and Strzepek, K.: Comprehensive assessment of the freshwater resources of the world, Stockholm Environment Institute, Stockholm, Sweden, 1997.

Rost, S., Gerten, D., Bondeau, A., Lucht, W., Rohwer, J., and Schaphoff, S.: Agricultural green and blue water consumption and its influence on the global water system, Water Resour. Res., 44, W09405, doi:10.1029/2007WR006331, 2008.

Shiklomanov, I. A.: Appraisal and assessment of world water resources, Water Int., 25, 11-32, 2000.

Siebert, S., Döll, P., Hoogeveen, J., Faures, J.-M., Frenken, K., and Feick, S.: Development and validation of the global map of irrigation areas, Hydrol. Earth Syst. Sci., 9, 535-547, doi:10.5194/hess-9-535-2005, 2005.
Taylor, K. E., Stouffer, R. J., and Meehl, G. A.: An overview of cmip5 and the experiment design, B. Am. Meteorol. Soc., 93, 485-498, 10.1175/BAMS-D-11-00094.1, 2012.

Vörösmarty, C. J., Green, P., Salisbury, J., and Lammers, R. B.: Global water resources: Vulnerability from climate change and population growth, Science, 289, 284-288, 2000.

van Vuuren, D., Edmonds, J., Kainuma, M., Riahi, K., Thomson, A., Hibbard, K., Hurtt, G., Kram, T., Krey, V., Lamarque, J.F., Masui, T., Meinshausen, M., Nakicenovic, N., Smith, S., and Rose, S.: The representative concentration pathways: an overview, Clim. Change, 109, 5-31, doi:10.1007/s10584-0110148-Z, 2011.

Wada, Y., van Beek, L. P. H., Viviroli, D., Dürr, H. H., Weingartner, R., and Bierkens, M. F. P.: Global monthly water stress: 2. Water demand and severity of water stress, Water Resour. Res., 47, W07518, doi:10.1029/2010wr009792, 2011.

Weedon, G. P., Gomes, S., Viterbo, P., Shuttleworth, W. J., Blyth, E., Österle, H., Adam, J. C., Bellouin, N., Boucher, O., and Best, M.: Creation of the WATCH Forcing Data and Its Use to Assess Global and Regional Reference Crop Evaporation over Land during the Twentieth Century, J. Hydrometeorol., 12, 823-848, doi:10.1175/2011jhm1369.1, 2011. 